\section{Circulação internacional de pesquisadores brasileiros: o caso da área de história}

\section{International circulation of Brazilian researchers: the case of History}

\author{
Marlon Salomon ${ }^{i}$ \\ 'Professor, Faculdade de História/Universidade Federal de Goiás. \\ Goiânia - GO - Brasil \\ orcid.org/0000-0002-2446-2141 \\ marlonsalomon@ufg.br \\ Marcelo de Souza Magalhães ${ }^{i i}$ \\ ii Professor, Escola de História/ \\ Universidade Federal do Estado do Rio de Janeiro. \\ Rio de Janeiro - RJ - Brasil \\ orcid.org/0000-0001-5231-5133 \\ marcelo.magalhaes@unirio.br
}

Recebido em 13 fev. 2020.

Aprovado em 18 ago. 2020.

http://dx.doi.org/10.1590/S0104-59702021000400009
SALOMON, Marlon; MAGALHÃES, Marcelo de Souza. Circulação internacional de pesquisadores brasileiros: o caso da área de história. História, Ciências, Saúde - Manguinhos, Rio de Janeiro, v.28, n.4, out.-dez. 2021, p.1079-1111.

Resumo

O artigo reúne e apresenta um amplo conjunto de dados sobre a circulação internacional de estudantes de doutorado e pesquisadores(as) pertencentes à comunidade historiográfica brasileira financiados(as) pela Coordenação de Aperfeiçoamento de Pessoal de Nível Superior, por meio de bolsas de doutorado sanduíche e de pósdoutorado. Analisa os registros anuais de bolsas concedidas entre 1998 e 2017 no intuito de observar sua evolução e o percentual anual de bolsistas no exterior. Compara a história com outras áreas do conhecimento e com o total de bolsas concedidas. Finalmente, apresenta os países e as principais instituições de destino desses bolsistas. Constata que essa área segue os mesmos caminhos da ciência brasileira no exterior.

Palavras-chave: história; mobilidade internacional; Coordenação de Aperfeiçoamento de Pessoal de Nível Superior (Capes); historiografia; internacionalização.

\section{Abstract}

The article collates and presents a wide range of data on the international circulation of doctoral students and researchers belonging to the Brazilian historiographical community funded by the Brazilian Federal Agency for the Support and Evaluation of Graduate Education, through doctoral grants with international internship and post-doctoral grants. It analyzes the annual records of scholarships awarded from 1998 to 2017, observing how they changed over time and the annual percentage of scholarship holders abroad. It compares the total number of scholarships in History and in other disciplines. Lastly, it lists the main countries and institutions where these individuals studied. It notes that this discipline follows the same path as Brazilian science abroad.

Keywords: history; international mobility; Brazilian Federal Agency for the Support and Evaluation of Graduate Education (Capes); historiography; internationalization. 
$\mathrm{A}$ pós-graduação brasileira apresenta um marco legal, ainda insubstituível, que remonta a 1965. Trata-se do parecer n.977 da Câmara de Ensino Superior (CES) do Conselho Federal de Educação (CFE), aprovado em 3 de dezembro. Sob a presidência de Antônio Ferreira de Almeida Júnior e relatoria de Newton Sucupira, o parecer foi assinado pelos demais membros da CES: Clóvis Salgado, José Barreto Filho, Maurício Rocha e Silva, Durmeval Trigueiro, Alceu Amoroso Lima, Anísio Teixeira, Valnir Chagas e Rubens Maciel. $\mathrm{Na}$ lista de nomes que discutiram e aprovaram o parecer existem intelectuais de peso no âmbito da Educação (CFE, 1965).

O parecer é fruto de uma demanda feita ao CFE por parte de Flávio Suplicy de Lacerda, ministro da Educação e Cultura do governo de Castelo Branco. O ministro, partindo da necessidade de implantar cursos de pós-graduação no ensino superior, solicitou ao conselho que definisse e regulamentasse tais cursos. No aviso ministerial existe a sugestão de que a pós-graduação se organize em dois cursos (mestrado e doutorado) e seja prioritariamente uma atribuição das universidades, em vez de ficar a cargo de instituições isoladas.

Percebe-se, apenas pelos títulos dos itens e subitens do parecer, o empenho por parte do relator e dos demais membros da Câmara em dar conta do solicitado pelo ministro: Definição dos cursos de pós-graduação, Origem histórica da pós-graduação, Necessidade da pósgraduação, Conceito de pós-graduação, Um exemplo de pós-graduação: a norte-americana, $A$ pós-graduação na Lei de Diretrizes e Bases, A pós-graduação e o Estatuto do Magistério, Definição e características do mestrado e doutorado (CFE, 1965).

A pós-graduação definida no parecer - estruturada em cursos de mestrado e doutorado, compostos por disciplinas, seminários, realização de pesquisa e defesa de um trabalho final - possui clara inspiração na experiência norte-americana. No Brasil, até então, não havia a tradição do mestrado, e o doutorado não se organizava como um curso, sendo seu formato definido pela instituição de ensino superior que atribuísse o título de doutor.

Ao consultar o ano de início de cada curso na base de Dados Abertos da Plataforma Sucupira, selecionando o ano de 2018, tem-se a devida noção da importância de 1965. Apenas 29 cursos de todas as áreas - 21 mestrados e oito doutorados - foram criados antes, sendo 28 entre 1960 e 1964 e um em 1931. ${ }^{1}$ Apesar de constatada a importância de 1965 com esses números, ao mesmo tempo, os programas anteriores ajudam a concluir o óbvio: a pós-graduação brasileira foi impactada pelo parecer, mas não é fruto exclusivo dele. A própria solicitação do ministro aponta para algum acúmulo acerca da experiência de pósgraduação existente até então. Se o parecer não é inaugurador da pós-graduação no Brasil, pode-se dizer, sem receio de simplificação, que, com ele, a partir da segunda metade dos anos 1960, surgem as bases legais para a estruturação, no futuro, do sistema nacional de pós-graduação que conhecemos hoje.

Qualquer indicador disponibilizado hoje pela Coordenação de Aperfeiçoamento de Pessoal de Nível Superior (Capes) - número de programas, cursos, alunos, titulados, docentes, publicações - sinaliza que tivemos, ao longo de cinco décadas, um processo vigoroso de implantação e consolidação da pós-graduação stricto sensu. Por exemplo, os dados presentes no GeoCapes ${ }^{2}$ mostram, em 2018, a existência de 6.476 cursos de pós-graduação, sendo 3.467 cursos de mestrado, 2.268 de doutorado e 741 de mestrado profissional. Em 1975, uma década após o parecer n.977, havia 370 cursos de mestrado e 
89 de doutorado (Capes, s.d.-b, p.197). Nos 43 anos entre 1975 e 2018, constata-se uma expansão muito significativa e consistente do sistema nacional de pós-graduação, com crescimento de $937 \%$ e $2.548 \%$ dos cursos de mestrado e doutorado, respectivamente. Trata-se de uma história de sucesso no âmbito do sistema de educação brasileiro, em que pesquisadores, instituições de ensino superior, institutos de pesquisa, governos e agências de fomento participaram.

Grande parte da pesquisa brasileira se desenvolveu, e ainda se desenvolve, na pósgraduação. Existe forte sinergia entre a realização de pesquisa de ponta em grupos e laboratórios vinculados aos programas de pós-graduação e a formação de quadros para atuar nas instituições de ensino superior, na educação básica, nos órgãos do Estado e nos demais setores da sociedade brasileira.

É consenso entre a comunidade acadêmica, e para além dela, que a pós-graduação é um exemplo exitoso que deve ser reproduzido nos demais níveis do sistema educacional brasileiro. Isso não significa dizer que não avançamos, nos últimos trinta anos, na educação básica e no ensino de graduação. Houve aumento nada desprezível do número de alunos em todos os níveis do sistema educacional. O grande desafio é associar expansão com qualidade do sistema.

As agências de fomento federais - Capes e Conselho Nacional de Desenvolvimento Científico e Tecnológico (CNPq) - participaram dessa história desde o início da pósgraduação estruturada em cursos. Mesmo antes, nos anos 1950, ambas, com nomes e estatutos jurídicos diferentes dos atuais, tiveram a função de auxiliar nos processos de qualificação dos docentes que atuavam no ensino superior e no desenvolvimento da pesquisa no Brasil. Criadas em 1951, no segundo governo de Getúlio Vargas, próximas de completar 70 anos, os fomentos - bolsa e auxílio financeiro aos programas de pós-graduação - dessas agências foram decisivos para a montagem e a consolidação do sistema. ${ }^{3}$ Em sua origem, as atuais agências de fomento apoiavam a qualificação de docentes do ensino superior e a formação de pesquisadores(as) por meio da concessão de bolsas, mesmo que em número pequeno, para a realização de cursos de doutorado no exterior e, excepcionalmente, de mestrado. Tal ação tinha por objetivo incentivar a constituição mais significativa de núcleos de pesquisa no Brasil. A gestão Darcy Closs (1974-1979) na Capes criou a bolsa de doutorado sanduíche, num formato um pouco diferente do atual (Closs, 2002, p.81). Isso demonstra uma preocupação sempre presente de inserção da pesquisa produzida no país na comunidade científica internacional - inicialmente, ao menos quando se tratava da formação de quadros qualificados, por meio da obtenção do título de doutor em instituições estrangeiras.

A Capes, ao longo do tempo, apesar de não ser a única responsável pelo sucesso da pós-graduação, adquiriu papel cada vez mais importante. Certamente, isso se deve ao fato de a agência ter se tornado, no Ministério da Educação, a responsável por, de forma associada, fomentar, avaliar e autorizar o funcionamento dos programas de pós-graduação no país. Tal associação, com o tempo, reforçou ainda mais o caráter indutor da agência na constituição de políticas públicas para a pós-graduação. Desde 1976, a agência avalia os cursos de pós-graduação existentes no país. Com o tempo, a Capes passou a vincular os valores transferidos para cada curso - bolsas e financiamento para o funcionamento - aos resultados alcançados na avaliação. 
Desde o parecer n.977, o Estado brasileiro preocupou-se em constituir políticas públicas para o desenvolvimento da pós-graduação. Até 2020, foram formulados cinco documentos intitulados Plano Nacional de Pós-graduação (PNPG), todos com a preocupação de fazer um histórico da pós-graduação no país, analisar a situação do sistema e traçar metas para determinado período.

No I PNPG (1975-1979), formulado durante o governo de Ernesto Geisel, em que os cursos de pós-graduação existentes eram em sua maioria novos, a tônica foi realizar esforços para a institucionalização do sistema de pós-graduação. O plano estabeleceu três diretrizes: (1) transformar a pós-graduação em atividade regular nas universidades, com financiamento estável; (2) elevar o padrão de desempenho e racionalizar o uso de recursos nos cursos de pós-graduação, com vistas a reduzir a evasão e titular mais alunos; (3) planejar a expansão de forma equilibrada das áreas de conhecimento e entre as regiões do país (MEC, s.d.).

No II PNPG (1982-1985), elaborado sob o governo de João Figueiredo, são listados os seguintes problemas estruturais, entendidos como empecilhos ao desenvolvimento do sistema de pós-graduação: (1) dependência de recursos de fora do orçamento regular das instituições de ensino superior; (2) sujeição a repentinos cortes de recursos; (3) instabilidade empregatícia dos docentes, técnicos e pessoal de apoio (Capes, s.d.-a). A tônica em garantir a institucionalização da pesquisa e da pós-graduação nas universidades mantém-se nesse segundo plano. Há preocupação com a melhoria da qualidade dos cursos, com a compatibilidade da pós-graduação e da pesquisa voltada para as prioridades nacionais, e com a coordenação entre diferentes instâncias de governo que atuam na área. Como diretrizes, lista o aperfeiçoamento do sistema de avaliação da pós-graduação, com o objetivo de melhorar a sua qualidade, e a revisão dos mecanismos que determinam o seu financiamento. O plano sinaliza para algo que se consolidará e passará a ser coordenado pela Capes: a associação entre avaliação e fomento.

No III PNPG (1986-1989), construído durante o governo de José Sarney, o diagnóstico é de que faltam pesquisadores para o Brasil atingir plena capacitação científica e tecnológica, e a solução apontada é iniciar um forte programa de formação de quadros. Como conquistas dos planos anteriores, mencionam-se: (1) o aumento do regime de tempo integral e dedicação exclusiva nas instituições federais de ensino superior; (2) a implantação do Programa Institucional de Capacitação Docente (PICD), para melhor qualificar os docentes que atuam nas universidades; (3) a implantação e a consolidação do sistema de acompanhamento e avaliação da pós-graduação. Tais conquistas, na avaliação presente no documento, tornaram perceptível uma melhora na qualidade do sistema de pós-graduação. Mais uma vez, há o compromisso de institucionalizar e consolidar a pós-graduação. O plano estabelece três objetivos: (1) consolidar e melhorar o desempenho dos cursos de pós-graduação; (2) institucionalizar a pesquisa nas universidades; (3) integrar a pós-graduação no sistema de ciência e tecnologia, aproximando-a do setor produtivo (Capes, s.d.-b).

Por que mencionar cada plano com certo grau de detalhamento? Primeiro, para mostrar que a pós-graduação foi alvo da atenção de diferentes governos. Além disso, para perceber que há algum tipo de continuidade entre os planos quando constroem um diagnóstico e listam objetivos e diretrizes da pós-graduação. Os planos claramente constituem-se como políticas públicas complementares. No caso dos três primeiros, que contemplam as décadas 
iniciais de configuração do sistema de pós-graduação, mais uma vez, os esforços despendidos são voltados para a institucionalização. Há o reconhecimento de que um grande esforço ainda precisa ser feito para conseguir a manutenção de um sistema de pós-graduação com qualidade, em funcionamento contínuo. Tal esforço envolvia pensar o lugar ocupado pela pós-graduação nas universidades; o financiamento dos cursos, que fosse menos suscetível a restrições orçamentárias; a forma de expansão do sistema de pós-graduação entre as regiões; a qualidade dos cursos oferecidos, no sentido de reduzir a evasão e aumentar a titulação; e, por fim, a constituição de um quadro mais regular de docentes e técnicos que trabalhem nos cursos, o que implica enfrentar a questão do regime de trabalho nas universidades.

Nos últimos planos, de 2005-2010 e 2011-2020, ambos feitos na gestão de Jorge Almeida Guimarães na presidência da Capes, nos governos de Luiz Inácio Lula da Silva, o diagnóstico é o de que se alcançou a consolidação do sistema, ou seja, os esforços não eram mais no sentido de garantir a sua existência. O grande objetivo traçado para o período 2005-2010 é expandir o sistema de forma significativa, o que implica abrir mais cursos de pós-graduação em diferentes regiões do país e alcançar um expressivo aumento do número de pós-graduandos, seguindo o que era feito desde 1996 (Capes, 2004).

A preocupação com a internacionalização da pós-graduação brasileira ganha destaque nos dois últimos planos. Impacto e relevância são palavras que passam a ser incorporadas ao vocabulário da avaliação do sistema de pós-graduação. No PNPG 2005-2010, existe indicativo de que se deve estimular a cooperação internacional nas universidades. Isso significa, por exemplo, institucionalizar o intercâmbio entre alunos e professores. $\mathrm{O}$ plano lista cinco modalidades de cooperação internacional: (1) ampliar a cooperação para uma relação de reciprocidade e simetria entre instituições nacionais e estrangeiras; (2) compartilhar orientação de doutorandos com pesquisadores estrangeiros; (3) apoiar estágio de pós-doutoramento para jovens doutores; (4) ampliar intercâmbio de graduandos, com o objetivo de estimular o ingresso na pós-graduação; (5) estimular parcerias e redes de pesquisa na cooperação Sul-Sul (Capes, 2004).

No PNPG 2011-2020, há, pela primeira vez, um item específico intitulado "Internacionalização da pós-graduação e a cooperação internacional". Existe menção sobre ações de cooperação internacional em outros planos. A novidade é o destaque em um item com mais páginas e o uso da palavra "internacionalização". O item aborda o número de citações e o impacto dos artigos produzidos pela ciência brasileira, vistos como formas de medir a sua presença na comunidade científica internacional. Além disso, cita, como indicativo de reconhecimento, a participação da ciência brasileira em associações e fóruns científicos internacionais. Em seguida, analisa a cooperação internacional existente e a atuação da Capes, do CNPq e da Financiadora de Estudos e Projetos (Finep). Por fim, menciona algumas instituições de pesquisa e empresas que mantêm graus importantes de cooperação internacional, por exemplo: o Instituto Butantan, a Fiocruz e a Petrobras (Capes, 2010).

A compreensão de que a comunidade científica não tem fronteira e de que para se fazer ciência são necessárias conexões internacionais está presente desde a constituição das agências de fomento federais nos anos 1950, em que o esforço era qualificar os docentes que atuavam nas universidades e construir uma estrutura de pesquisa no país. Como vimos, Capes e CNPq esforçavam-se para enviar profissionais para o estrangeiro a fim de 
realizar seus doutorados. Com a institucionalização da pós-graduação, entre as décadas de 1960 e 1990, com a abertura de cursos de doutorado no país, a tendência é a alteração do tipo de mobilidade internacional, deixando, com o tempo, de ser significativa a saída para a realização de doutorado pleno e aumentando a de doutorado sanduíche. Junto com essa mudança, com o crescimento do número de doutores no país, também passa a ser importante o estágio de pós-doutoramento no estrangeiro. Essas três ações de mobilidade internacional, além da participação em encontros científicos, são as formas de intercâmbio experimentadas há muitas décadas no Brasil.

Nos dois últimos planos, a grande diferença é que a inserção da ciência brasileira na comunidade científica internacional, por meio não apenas da circulação, mas pela construção de projetos e redes de pesquisa, passa a servir como diferenciador para avaliar a qualidade do sistema. A inserção internacional torna-se crivo que certifica a qualidade da ciência produzida nos programas de pós-graduação. Se a importância da inserção internacional aparece com destaque em tais planos, ganhando um item exclusivo sobre internacionalização no PNPG 2011-2020, esse fenômeno não é do século XXI nem peculiar à ciência brasileira.

No Brasil, 1998 é um marco do debate sobre a importância da inserção internacional da ciência, ao menos para o sistema nacional de pós-graduação. Trata-se do ano em que a avaliação da Capes muda a sua escala de qualificação dos programas, passando dos cinco estratos (A a E), vigentes desde os anos 1970, para sete estratos (1 a 7). O termo "excelência" passa a qualificar os cursos que alcançam as notas 6 e 7. Excelência, no caso, significa tratarse de cursos equivalentes aos melhores existentes no mundo.

Há 22 anos, o debate sobre internacionalização e inserção internacional das comunidades científicas locais ganhou relevância no Brasil, particularmente no âmbito dos programas de pós-graduação e no contexto dos ciclos avaliativos promovidos pela Capes. Sem dúvida, esse debate pertence a uma discussão mais ampla e que diz respeito aos novos processos econômicos globais e a como a produção do conhecimento científico se insere no interior desses processos. Nosso objetivo, em relação a essa extensa, profunda e densa discussão, é bastante modesto. Não falaremos de "internacionalização", processo que remete a um espectro amplo de ações e iniciativas, com qualidades e níveis distintos, pois pretendemos apenas abordar o seu grau mais elementar, aquele ligado à circulação de estudantes e pesquisadores(as) pertencentes à comunidade historiográfica brasileira. O objetivo deste artigo é mapear, reunir e apresentar uma série de dados sobre mobilidade internacional de historiadores(as) brasileiros(as) financiados(as) pela Capes entre 1998 e 2017.

Não consideramos, neste estudo, os dados sobre doutorado pleno no exterior. A partir dos anos 1990, a expansão e a progressiva consolidação dos cursos de pós-graduação brasileiros conduziram as políticas de qualificação de recursos humanos a privilegiar programas como os de doutorado sanduíche (Rocha, 2002; Lombas, 2017). Em meados da década de 1990, por exemplo, o número de bolsas concedidas pelas Capes para doutorado sanduíche (154 bolsas) era irrisório se comparado com o de doutorado pleno (943 bolsas). A partir de 1998, essa distância diminuiu gradativamente a cada ano. Em 2001, essa diferença tornou-se mínima (710 bolsas de doutorado sanduíche contra 931 de doutorado pleno). Em 2003, o número de concessões desses dois programas era praticamente o mesmo, mas a partir do ano seguinte, e ao longo de toda a série aqui em análise, o número de bolsas sanduíches 
passou a ser maior que as de doutorado pleno (mesmo no momento de cortes de bolsas em 2015-2016). Em 2008, as bolsas concedidas para doutorado pleno no exterior eram menos da metade das concedidas para estágio doutoral. A cronologia dessa nova orientação das políticas de qualificação de pessoal da agência federal mais ou menos coincide com os anos considerados na série de nossa análise. Assim, restringimos nossa investigação às bolsas de pós-doutorado e doutorado sanduíche.

Em relação aos números aqui reunidos é preciso, do ponto de vista metodológico, alguma precaução. A Capes disponibiliza no GeoCapes as planilhas anuais com os registros de bolsas ativas no exterior. Se somarmos ano a ano, de 1998 a 2017, atingiremos o total de 17.242 registros de bolsas de pós-doutoramento concedidas para todas as áreas do conhecimento. Isso não quer dizer que a Capes, ao longo dessas quase duas décadas, concedeu 17.242 bolsas ou que esse foi o número de bolsistas contemplados durante esse período. A agência federal realiza esse registro de forma anual, anotando o número de bolsas ou concessões ativas a cada ano. Isso quer dizer que uma concessão, por exemplo, que tenha se iniciado em agosto de determinado ano com prazo de conclusão em julho do ano seguinte aparecerá como um registro na planilha de cada um desses dois anos. Embora haja aí dois registros, há apenas uma bolsa e um único bolsista. Como esses registros não são individualizados - o que nos impediu de analisar outras questões relevantes, como, por exemplo, aquelas ligadas a gênero e raça -, torna-se difícil eliminar um deles de modo a se definir objetivamente a evolução do número de bolsas concedidas durante esse período. Isso também se aplica aos registros de bolsa sanduíche. É preciso, portanto, levar isso em consideração, sobretudo mais à frente, na análise dos países e das instituições em que esses estágios foram realizados. O importante, a nosso ver, é que esses dados indicam grandes tendências da circulação internacional.

Este texto encontra-se dividido em duas seções. Na primeira, tratamos das bolsas concedidas para estágio de pós-doutorado e, na segunda, das concedidas para doutorado sanduíche. Em cada uma delas, buscamos avaliar o mesmo conjunto de dados. Assim, partimos dos números gerais de registros anuais de bolsas ativas no exterior para, em seguida, aproximá-los, no primeiro caso, do número de docentes vinculados(as) a programas de pósgraduação e, no segundo, do número de matrículas em cursos de doutorado no país. Essa aproximação permite observar o percentual anual de pesquisadores(as) e doutorandos(as) no exterior. Depois, analisamos esses mesmos números considerando, todavia, apenas a área de história, e aproximando-a de outras pertencentes às humanidades. Finalmente, na última parte de cada uma dessas seções, apresentamos os números relativos à geografia da circulação internacional da historiografia brasileira, considerando, num primeiro momento, os países de destinação dos pesquisadores(as) e doutorandos(as) e, finalmente, as principais instituições de acolhimento desses(as) bolsistas.

A história da historiografia ganhou enorme relevância no Brasil nos últimos anos. Os trabalhos produzidos nesse domínio ampliaram sobremaneira nosso conhecimento a respeito da história da ciência histórica, em suas diferentes abordagens e múltiplas tematizações. Quando se fala, todavia, das relações entre a historiografia brasileira e a estrangeira, a abordagem, em geral, costuma apenas enfatizar a história e os processos de importação, introdução, recepção e aclimatação de tradições e tendências teórico- 
metodológicas internacionais no campo historiográfico brasileiro. Embora procure inscreverse nos mesmos esforços desse movimento observado nos últimos anos, nosso trabalho pretende tratar de uma questão um pouco negligenciada por esses estudos, a saber, reunir um conjunto de evidências que permita reconstituir alguns dos caminhos percorridos pelos(as) historiadores(as) no exterior e elementos de sua geografia internacional no início deste novo século. Acreditamos que essas evidências ajudem, por outras vias, a lançar novas luzes sobre os processos de circulação internacional dessas tradições e tendências.

\section{Estágio de pós-doutorado}

\section{Números gerais}

Consideremos, inicialmente, o número de bolsas concedidas pela Capes para todas as áreas do conhecimento, entre 1998 e 2017. Em 1998, ela mantinha 266 estagiários(as) realizando pós-doutorado no exterior. Nos dois anos seguintes, esse número pouco oscilou. Em 2001, houve uma primeira variação positiva significativa, com aumento de $52 \%$ em relação ao ano anterior, alcançando 407 bolsas ativas no exterior. Entre 2004 e 2008, esse número mais que dobrou, atingindo 922 registros. Nos dois anos seguintes, malgrado o contexto da crise financeira de 2008, o número de concessões permaneceria estável. ${ }^{4}$ A partir de 2011, com a criação do Programa Ciência sem Fronteiras (CsF), houve um crescimento exponencial do número de bolsas concedidas para essa ação de internacionalização, saindo de 933 estagiários(as) em 2010, um ano antes de sua criação, para 2.041 estagiários(as) em 2015. Em 2016, houve queda de quase 50\% nesse número em função dos cortes orçamentários ocorridos a partir de 2015 (Figura 1).

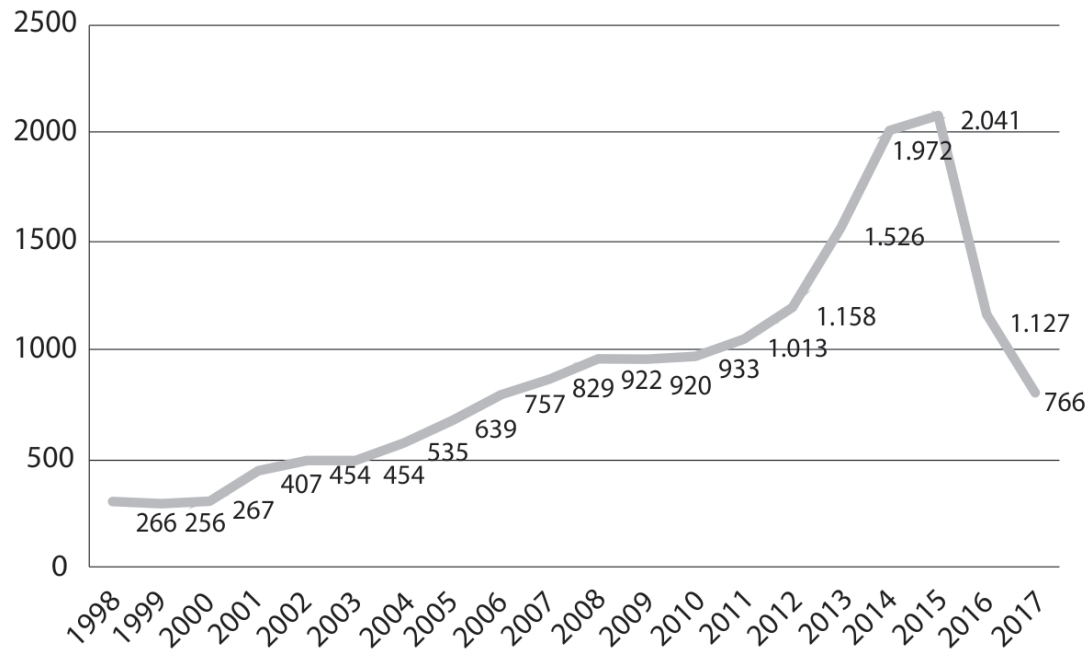

Figura 1: Gráfico do número anual de estagiários de pós-doutoramento no exterior com bolsa Capes, 1998-2017 (Fonte: GeoCapes) 
O crescimento do número de bolsas, ao longo dessas duas décadas, é evidente, e não seria necessário insistir nisso. Seria preciso, todavia, encontrar algum parâmetro que inscrevesse esses números no campo científico brasileiro, de modo a relacionar o aumento dessa oferta com o aumento da demanda potencial pela realização de um estágio de pesquisa no exterior. Poderíamos relacionar esse número com o de doutores(as) titulados(as) anualmente a partir de 1998. Sem dúvida, este último número indica o aumento do potencial de demanda por estágios pós-doutorais. Acreditamos, todavia, que outro dado nos permite ancorar de forma mais interessante essa expansão do número de bolsas no campo científico brasileiro: o que considera a evolução do número de professores(as) doutores(as) vinculados(as) a programas de pós-graduação - docentes permanentes e colaboradores(as). Com isso, não estamos sugerindo que professores(as) que não atuam na pós-graduação stricto sensu não realizaram ou realizam esse estágio no exterior. Muitos professores(as) vinculados(as) a instituições que não possuem programas de pós-graduação tiveram suas propostas aprovadas em editais durante o período em questão. Da mesma forma, há que considerar que muitos(as) recém-doutores(as) sem vínculos empregatícios realizaram estágios no exterior por meio de projetos e programas especiais vinculados a acordos bilaterais específicos de cooperação.

Essa opção reduz um pouco a série a ser considerada. Foi apenas em 2004 que a estrutura do corpo docente dos programas de pós-graduação, dividida entre docentes permanentes, colaboradores(as) e visitantes, foi estabelecida (Capes, 3 ago. 2004). Esse ano, portanto, marca o início de uma série regular que pode ser utilizada para nosso propósito.

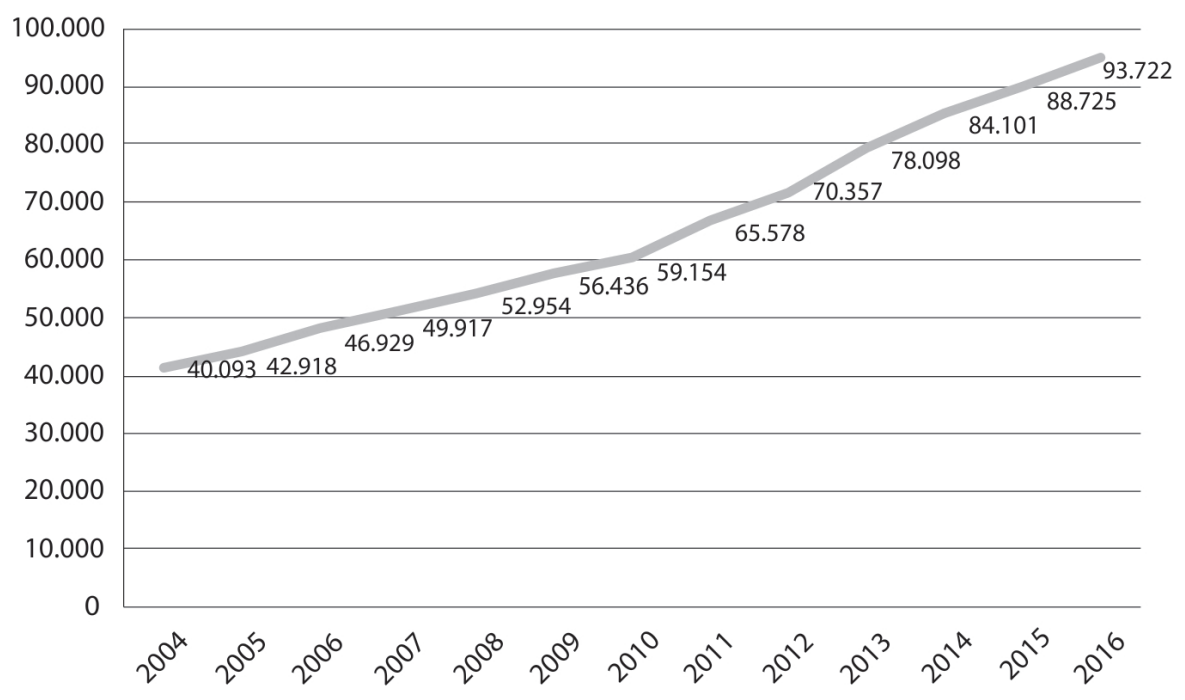

Figura 2: Gráfico do número de docentes permanentes e colaboradores(as) vinculados(as) a programas de pós-graduação stricto sensu, 2004-2016 (Fonte: GeoCapes)

Como se pode observar na Figura 2, em 12 anos, houve um crescimento expressivo do número de professores(as) doutores(as) atuando em cursos de mestrado e doutorado no país. A linha de expansão seguiu ao menos duas tendências durante esse período. Entre 
2004 e 2010, houve acréscimo claramente regular, pois a cada ano em torno de três mil novos(as) docentes foram incorporados(as) ao sistema. Durante esse período, houve um crescimento de 47,5\% no número de docentes. A partir de 2011, com a criação de novos programas de pós-graduação, muito em função das novas condições proporcionadas pelo programa de Reestruturação e Expansão das Universidades Federais (Reuni) ${ }^{5}$ e como uma resposta ao novo PNPG, a velocidade da incorporação de novos(as) pesquisadores(as) ao sistema foi ainda maior, com aumento de 58,5\% no número de docentes.

A rápida comparação entre os dois gráficos (Figuras 1 e 2) nos mostra, concentrando-se apenas entre 2004 e 2016, que o crescimento da oferta de bolsas pela agência brasileira foi muito maior que o da demanda, considerando-se apenas os/as docentes vinculados(as) a programas de pós-graduação. O crescimento do número de docentes foi de $134 \%$, e o da oferta de novas bolsas, de 334\%. As possibilidades, portanto, de qualificação, atualização, capacitação e inserção da ciência brasileira em redes internacionais de produção e circulação do saber ampliaram-se significativamente.

Mas esse aumento não foi linear e é preciso relativizá-lo, sobretudo porque essa ampliação da oferta esteve fortemente concentrada nos anos de vigência do CsF, portanto, nos últimos anos da série em questão. Trata-se (Figura 3) de projetar uma relação simples entre a evolução anual do número de bolsas e o crescimento do número de professores(as) atuando em cursos de mestrado e doutorado.

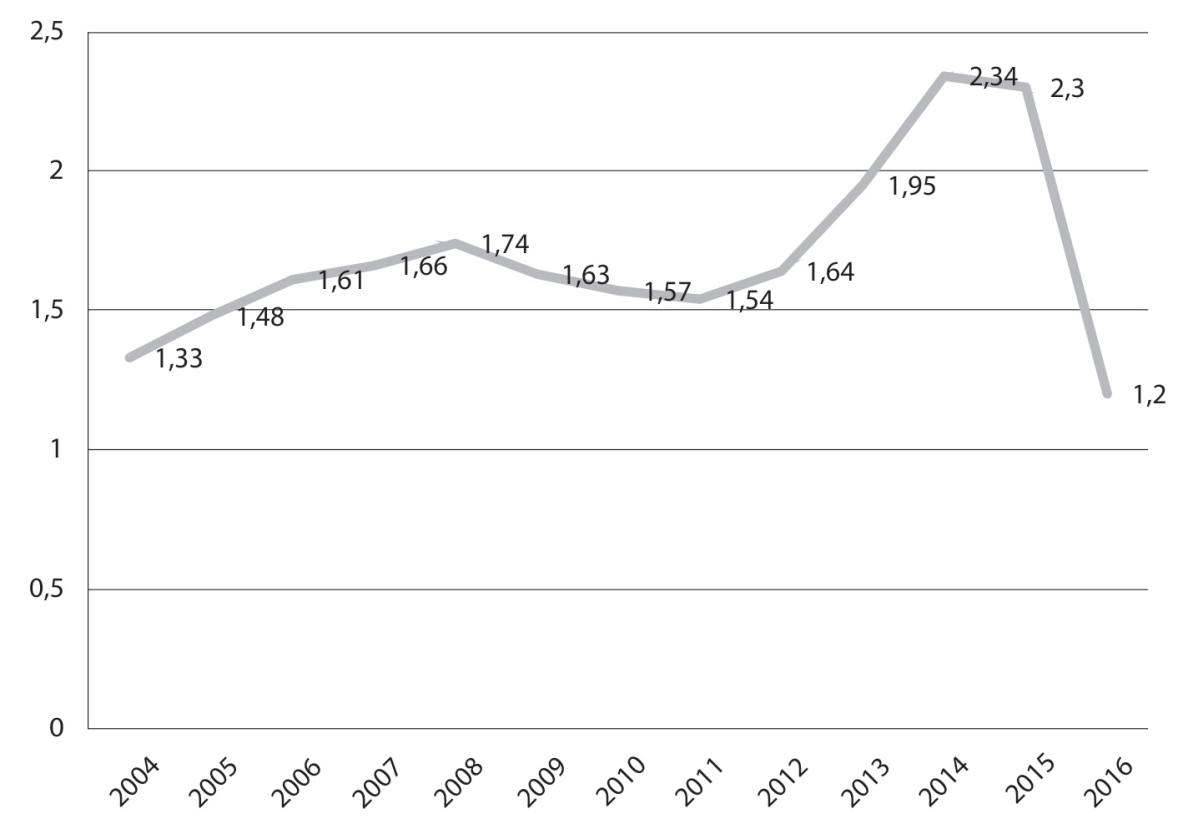

Figura 3: Gráfico da relação entre o número anual de bolsas concedidas e o número de docentes vinculados(as) a programas de pós-graduação stricto sensu, 2004-2016 (Fonte: GeoCapes) 
Se relacionarmos o crescimento anual do número de docentes e o de bolsas, encontraremos ao menos três tendências nessa evolução recente. O fato de o número de bolsas anualmente ativas ter dobrado, entre 2004 e 2008, permitiu que o aumento da oferta acompanhasse o da demanda potencial. Nos três anos seguintes, houve nítida queda nessa proporção. Isso ocorreu em função de uma quase estagnação da oferta acompanhada, todavia, de continuidade da ampliação do número de doutores(as) atuando na pós-graduação. A partir de 2012, os efeitos do CsF tornam-se nítidos no aumento dessa relação, atingindo seu ápice em 2014, com uma ligeira queda em 2015, antes de entrar em colapso em 2016, e voltar a um patamar um pouco abaixo daquele existente em 2004. Os números finais dessa série tornam-se ainda mais impressionantes se lembrarmos que ocorreram sobre uma base de docentes que cresceu rapidamente a partir de 2011.

Antes de passarmos aos números da área de história, uma palavra sobre o Programa CsF. Anunciado em julho de 2011, ele foi instituído pelo decreto n.7.642, de 13 de dezembro de 2011. O grande arco das humanidades, como se sabe, não foi incluído na lista dos "temas de interesse para o Brasil" (Capes, CNPq, 2011, p.6). O Programa integrava-se à pauta neodesenvolvimentista do novo governo de Dilma Rousseff. Seu objetivo geral era

promover de maneira acelerada o desenvolvimento tecnológico e estimular os processos de inovação no Brasil por meio da promoção da mobilidade internacional docente, discente de graduação e pós-graduação, de pós-doutorandos e pesquisadores brasileiros, estimulando a inserção das pesquisas feitas nas instituições brasileiras às melhores experiências internacionais (Capes, CNPq, 2011, p.6).

Seu objetivo era enviar $101 \mathrm{mil}$ bolsistas ao exterior ao longo de quatro anos. A proposta inicial do programa reservava quase $60 \%$ dessas bolsas para doutorado sanduíche, doutorado pleno e pós-doutorado. Rapidamente, percebeu-se que as estimativas e projeções feitas pelos técnicos das agências estatais não eram factíveis com as metas traçadas e que seria preciso concentrar a mobilidade internacional em estudantes de graduação (Chaves, 2015, p.91) - até 2016, 78,9\% dos(as) bolsistas enviados(as) ao exterior correspondiam a alunos(as) da graduação (Borges, Garcia-Filice, 2016, p.78). Isso tinha várias implicações: uma delas, prática, dizia respeito ao domínio de línguas estrangeiras nesse nível de formação; outra, político-científica, dizia respeito a uma mudança de orientação das estratégias de inserção internacional, já que historicamente a internacionalização da ciência brasileira fez-se privilegiando a pós-graduação e a mobilidade de pesquisadores(as) (Borges, Garcia-Filice, 2016, p.79). Parte significativa das críticas que seriam feitas ao programa girariam em torno disso. Nosso objetivo aqui não é fazer uma avaliação crítica desse programa. ${ }^{6}$ Gostaríamos apenas de apontar como esses problemas, não previstos inicialmente no plano de ação do programa, acabaram por ampliar o número de bolsas disponíveis nas agências federais e por beneficiar as ciências humanas e aquelas outras percebidas como inaptas à aceleração e cujos temas de pesquisa são, de acordo com os termos do panfleto que o anunciou, sem interesse estratégico para o país. ${ }^{7}$ 


\section{Números na área de história}

Entre 1998 e 2008, observa-se que os registros anuais de bolsas no exterior concedidas para a área de história oscilaram entre 8 e 19. Foi somente a partir do CsF que um número expressivamente maior de bolsas foi concedido para essa área, saindo de 22 registros, um ano antes do lançamento desse programa, para 86, em 2015. Em 2017, após fortes cortes ocorridos no orçamento da Capes, o número de registros de estagiários da área no exterior voltou aos mesmos níveis observados antes da criação do CsF (Figura 4). Isso é bastante preocupante, se considerarmos que o número de doutores(as) titulados(as) e de docentes atuando em programas de pós-graduação aumentou significativamente no último decênio.

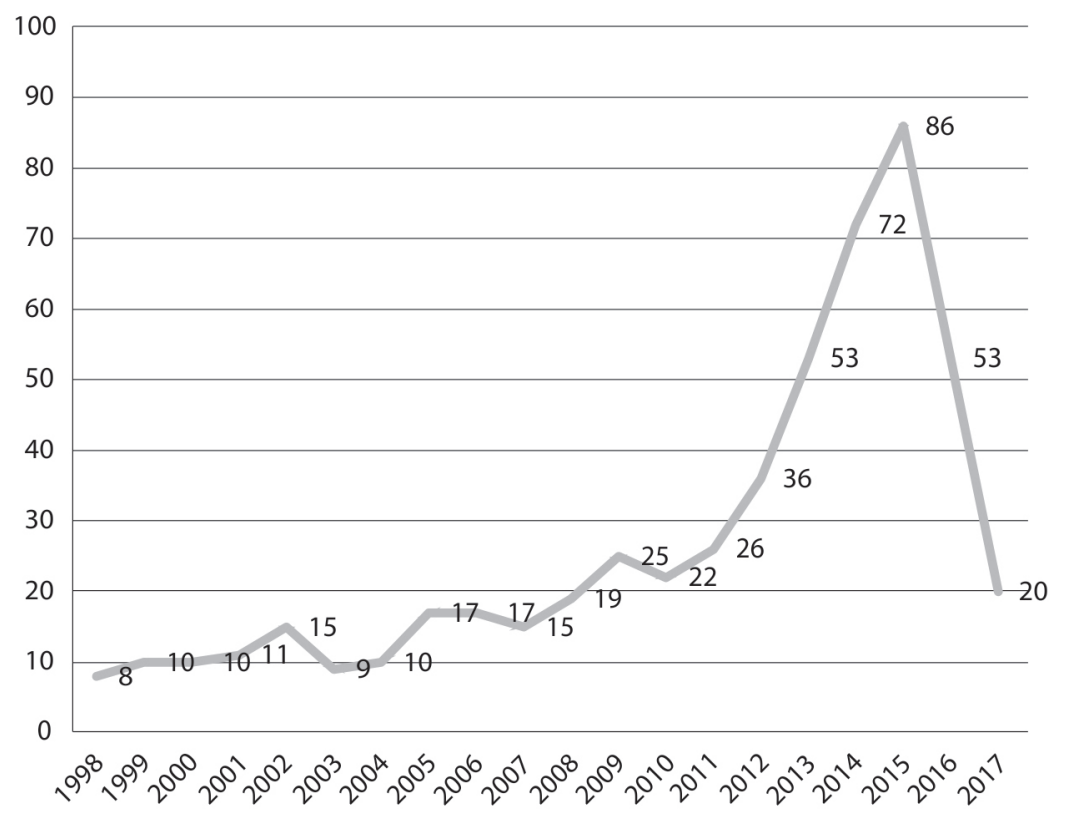

Figura 4: Gráfico do número anual de estagiários(as) de pós-doutorado no exterior, pertencentes à área de história, com bolsa Capes (Fonte: GeoCapes)

Em 12 anos, o número de docentes atuando nesse nível de formação praticamente triplicou, saindo de 693, em 2004, para 1.979, em 2016. ${ }^{8}$ Nos últimos vinte anos, houve ao menos três grandes ondas de expansão dessa área. Após quase três décadas de crescimento lento e paulatino, em 1998, havia vinte programas de pós-graduação em história no país. Entre 1998 e 2004, 13 novos cursos foram criados. Entre 2004 e 2007, registra-se um segundo grande salto nesse aumento, sobretudo com a criação de 16 novos cursos de mestrado, alcançando no final daquele triênio o total de 51 programas. Um terceiro grande e importante salto se registra entre 2010 e 2013, quando 13 novos cursos de doutorado foram abertos. Em linhas gerais, o gráfico na Figura 5 expressa - sem os dados entre 1998 e 2003 - o ritmo dessa expansão por meio da ampliação do número de docentes vinculados(as) a programas de pós-graduação em história. 


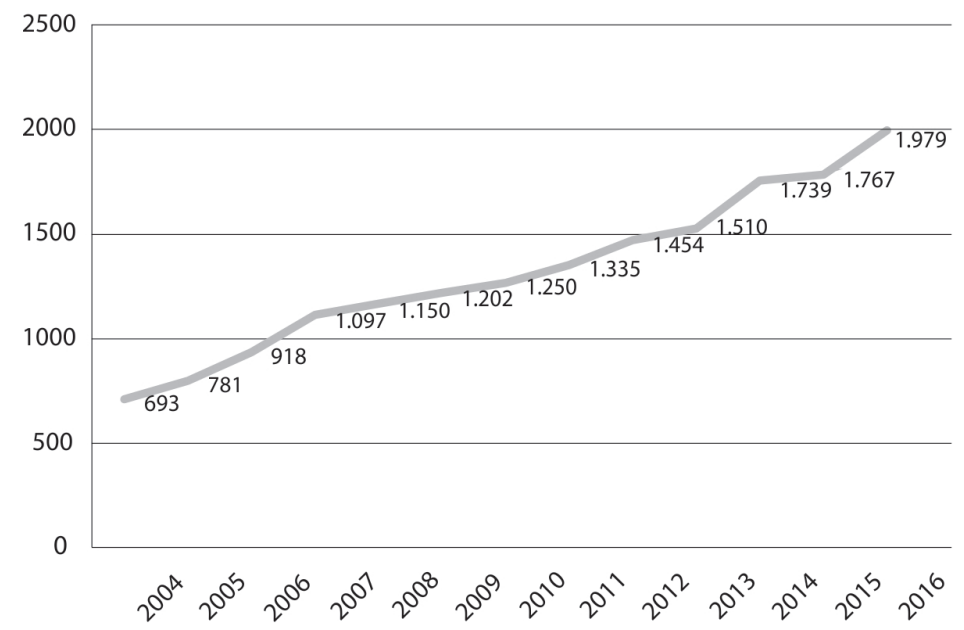

Figura 5: Gráfico do número de docentes permanentes e colaboradores(as) vinculados(as) a programas de pós-graduação em história, 2004-2016 (Fonte: GeoCapes)

Para encerrar esta primeira rodada de números sobre a circulação de pesquisadores(as) da área de história, relacionamos as duas séries de dados que acabamos de apresentar, tal como fizemos com os dados gerais. Ao mesmo tempo, cruzamos essa relação com aquela geral, que considera bolsas ativas anualmente em todas as áreas e a evolução do número de docentes vinculados(as) a programas de pós-graduação de todas as áreas.

A Figura 6 mostra que a área de história, com exceção de 2007, sempre teve uma proporção de pesquisadores(as) estagiando no exterior maior que a média geral de todas as áreas. Mostra também que essa área conseguiu, entre 2011 e 2015, proporcionalmente, enviar um número maior de pesquisadores(as) ao exterior.

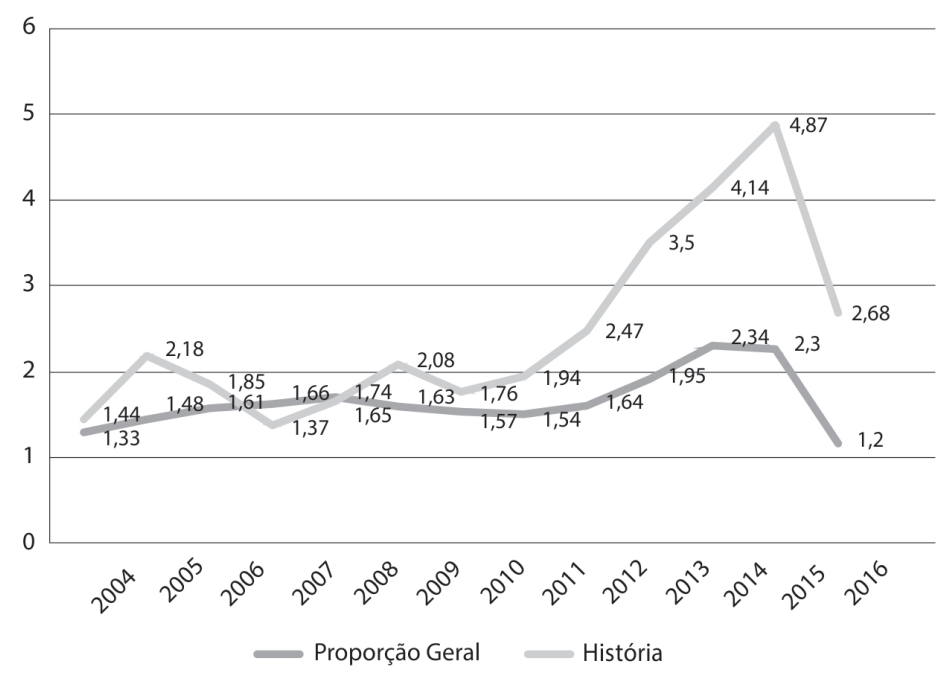

Figura 6: Gráfico da proporção de todas as áreas e da área de história com bolsa de pós-doutorado da Capes no exterior (Fonte: GeoCapes) 


\section{Destinos no exterior}

A circulação internacional dos(as) historiadores(as) brasileiros(as) entre 1998 e 2017 convergiu para poucos países. Todos os registros dividem-se em 16 destinos. Pouco mais da metade deles concentram-se em apenas dois: Portugal e França; e 78,5\% distribuem-se por somente quatro: Portugal, França, EUA e Espanha. A importância da península ibérica no tráfego internacional dos(as) historiadores(as) também é bastante evidente: quase 40\% das ocorrências de estágio pós-doutoral deram-se em Portugal e Espanha. Como se observa, a circulação internacional de historiadores(as) brasileiros(as) financiados(as) pela Capes concentrou-se na Europa ocidental e nas Américas. A par de um único registro de estágio na África, não há ocorrência de registros em Leste europeu, Oriente Médio, Ásia ou Oceania. Esse dado, embora não traduza objetivamente - conforme explicamos na introdução deste texto - a quantidade de bolsistas contemplados(as), os países e as instituições de realização dos estágios durante esse período, fornece, de forma aproximativa, números interessantes para avaliação dos principais destinos desse grupo de historiadores(as) brasileiros(as) no exterior (Tabela 1).

\begin{tabular}{cc}
$\begin{array}{c}\text { Tabela 1: Destinos dos(as) estagiários(as) de pós-doutorado } \\
\text { vinculados(as) à área de história no exterior, 1998-2017 }\end{array}$ & $\%$ \\
\hline País & 27,5 \\
\hline Prança & 24,5 \\
EUA & 15 \\
Espanha & 10,5 \\
Inglaterra & 6,7 \\
Itália & 3,9 \\
Argentina & 3,9 \\
Alemanha & 3,6 \\
Chile & 1,1 \\
Holanda & 0,9 \\
México & 0,8 \\
Bélgica, Canadá, Suíça & 0,4 \\
Escócia, Moçambique & 0,2 \\
\hline
\end{tabular}

Fonte: GeoCapes

É possível, da mesma forma, acompanhar as tendências da movimentação dos(as) historiadores(as) no exterior nessas quase duas décadas. Observemo-las no gráfico apresentado na Figura 7, considerando os cinco principais destinos no exterior, que concentram praticamente $85 \%$ dos registros. 


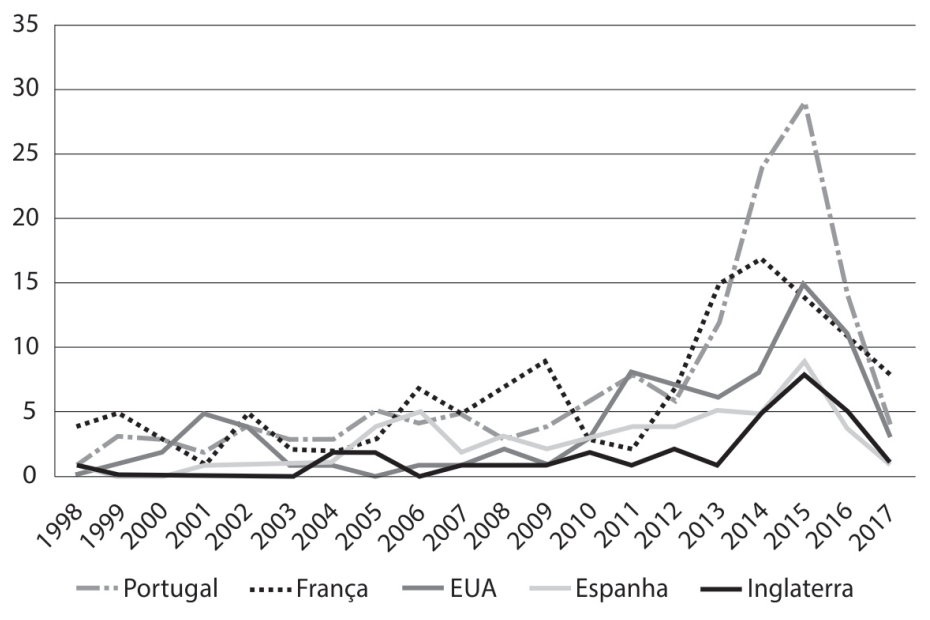

Figura 7: Tendências do movimento dos(as) historiadores(as) no exterior considerando os cinco principais destinos (Fonte: GeoCapes)

Apenas muito recentemente, a partir de 2013, a Inglaterra passou a ser um destino relevante para a historiografia brasileira em trânsito. O interesse pela realização de estágio nesse país, considerando 1998 como ponto de partida, foi sempre bastante marginal. Já no caso da Espanha, pode-se dizer que apenas após 2005 ela se firmou como um dos quatro principais destinos dos(as) pesquisadores(as) brasileiros(as). Já em relação aos EUA, observa-se que, entre 2000 e 2002, esse país chegou a ser o principal destino. Entre 2003 e 2009, por outro lado, ele praticamente saiu do radar dos(as) estagiários(as), voltando a ocupar uma posição de destaque nos registros em questão apenas em 2010. Já a França, ao longo de quase todo esse período, dividiu com Portugal o posto de principal destino dos(as) bolsistas(as) de pós-doutorado, ora à frente, ora em segundo lugar. A partir, todavia, do terceiro ano de implementação do CsF, Portugal se tornou incontestavelmente a principal destinação dos(as) estagiários(as). Proporcionalmente, o interesse pela França não parece ter acompanhado o mesmo crescimento do interesse por Portugal. Nesse mesmo período, os EUA parecem ter passado a rivalizar com mais consistência como segundo destino de interesse dos(as) historiadores(as) brasileiros(as) a ponto de, ainda em 2015, ter momentaneamente ultrapassado a França nos registros anuais da Capes. Se somarmos a isso a revalorização recente da procura por estágios na Inglaterra, poderíamos apontar uma tendência, nesses últimos anos, de inserção de historiadores(as) brasileiros(as) nas redes acadêmicas anglófonas ou tratar-se-ia de uma disposição momentânea? Isso indicaria uma tendência recente da diminuição do interesse brasileiro pela historiografia francesa ou tratar-se-ia de questão estritamente pontual?

Argentina, Itália e Alemanha, com praticamente o mesmo número (21, 21 e 19), concentram 11\% dos registros. Apenas recentemente esses três países adquiriram importância no quadro de destinos dos(as) pesquisadores(as) financiados(as) pela Capes. Antes de 2008, por exemplo, havia apenas um registro de estagiário(a) de pós-doutorado na Argentina, dois na Itália e cinco na Alemanha. Apenas este último país possuía até então um histórico mais consistente na série em tela. A partir de 2008, os registros crescem e tornam-se regulares para a Argentina. Nos casos da Itália e Alemanha, isso só ocorreu 
a partir de 2012, após a criação do programa CsF. Como se observa, apenas oito países concentraram 96\% dos(as) estagiários(as) de pós-doutorado.

Não são, todavia, apenas os/as historiadores(as) que possuem o seu horizonte acadêmico e científico orientado fundamentalmente para os cinco países exibidos na Figura 7. Em linhas gerais, essa é a orientação mais frequente da própria ciência brasileira considerando a totalidade de suas áreas. Isso quer dizer que mesmo um país como Portugal, cuja importância para seu conhecimento os historiadores costumam justificar por razões empíricas e arquivísticas, possui um peso importante no horizonte geral da ciência brasileira, ainda que esse país não seja considerado uma referência como produtor de ciência em nenhuma área de conhecimento e seja muitas vezes classificado como periférico no próprio sistema científico-tecnológico europeu. Se considerarmos os principais destinos dos(as) estagiários(as) de pós-doutorado financiados pela Capes de todas as áreas do saber, entre 1998 e 2017, observaremos que Portugal apenas não figurou entre os cinco primeiros em 1998 (sétima posição), 2001 (sexta posição) e 2002 (sexta posição). Entre 2005 e 2012, o país se tornou o quarto principal porto dos(as) bolsistas da Capes. Em 2013, desbancou a Espanha, alcançando a posição de terceiro principal destino. Em 2015 e 2016, ficou atrás apenas dos EUA, como o segundo principal destino desses(as) estagiários(as) - em 2016, voltou para terceiro, e, em 2017, ocupou o quinto lugar.

Ao longo desses 19 anos, ainda considerando todas as áreas de conhecimento, os EUA sempre figuraram como o principal destino dos(as) estagiários(as) de pós-doutorado brasileiros(as) financiados pela Capes. O segundo posto nesse quesito, com exceção de 2015 e 2016, sempre foi ocupado pela França. Aliás, é interessante observar que esses dois países, considerando a série 1998-2017, sempre atraíram parte importante dos pesquisadores brasileiros. Nos primeiros anos dessa série, entre 50\% e 60\% dos(as) pesquisadores(as) brasileiros(as) estagiaram nesses países. E, se a partir de 2005 há um processo de desconcentração desses estágios, cabe ressaltar que ao longo desses 19 anos, anualmente, esses dois países sempre atraíram em torno de $40 \%$ dos estágios de pósdoutorado, considerando-se todas as áreas do conhecimento.

Finalmente, podemos recordar um importante deslocamento do destino do conhecimento brasileiro no período em análise, considerando dessa vez todas as modalidades de bolsas concedidas - e não apenas as de pós-doutorado - no exterior pela Diretoria de Relações Internacionais da agência federal. Em 2001, o principal destino dos bolsistas brasileiros eram os EUA, seguidos da França e do Reino Unido. Nos dez anos seguintes, essa geografia sofreu importante reconfiguração, e, em 2011, a França concentrava 30\% de todos os bolsistas brasileiros no exterior, seguida pelos EUA (21\%) e por Portugal (10\%). Como se observa, na primeira década do milênio, o país de Fernand Braudel suplantou os EUA nesse registro. ${ }^{9}$ Já em 2012, puxado sobretudo pelas bolsas de graduação sanduíche e por uma reorientação da política brasileira de internacionalização implementada pelo governo Dilma Roussef, os EUA voltaram a dominar com bastante folga esse cenário, em que França e Portugal guardaram, todavia, suas posições.

Isso nos mostra como o conhecimento histórico, malgrado suas especificidades e singularidades, insere-se no mesmo movimento mais geral da ciência brasileira. Ao mesmo tempo, porém, evidencia como esse movimento é, em grande medida, induzido por políticas e ações estatais que buscam determinar e dirigir os fluxos e a circulação internacional de estudantes e pesquisadores(as). O Brasil, ou a ciência brasileira, foi um 
foco de disputa desses dois países (EUA e França). A história da criação e da evolução de programas estatais indissociavelmente ligados a questões geopolíticas (acordo Usaid [Agência dos Estados Unidos para o Desenvolvimento Internacional], Fundação Ford, Fulbright e Capes-Cofecub [Comité Français d'Evaluation de la Coopération Universitaire et Scientifique avec le Brésil], entre outros) certamente ajudaria a explicar a preponderância desses dois países na lista dos mais valorizados pela ciência brasileira e a compreender as condições institucionais e científicas de reprodução da inserção dessa ciência na geografia internacional do conhecimento.

Não deixa de ser surpreendente o peso que as instituições científicas e acadêmicas francesas ocupavam no início deste novo século na geografia internacional da ciência brasileira (lembremos: em 2011, um(a) bolsista em cada três, de qualquer nível e de qualquer área, estagiava então em alguma instituição francesa). Isso porque, após um período de disputa equilibrada, nos anos 1980 e 1990, os EUA tornaram-se um país hipercentral no sistema científico global, e as universidades norte-americanas tornaram-se hegemônicas internacionalmente (Heilbron, 1999; Brisson, 2016; Sapiro, 2018). Vemos que, apesar de o inglês ter se tornado dominante no world language system (Swaan, 2001), o francês permanece uma língua central na cultura científica e acadêmica brasileira, e as universidades francesas gozam de imenso prestígio no país.

\section{Instituições de destino}

Para encerrar a apresentação desta primeira série de dados sobre a circulação internacional de historiadores(as) em estágio pós-doutoral, apontamos na Figura 8 os principais endereços institucionais dos(as) pesquisadores(as) ao longo dessas duas décadas.

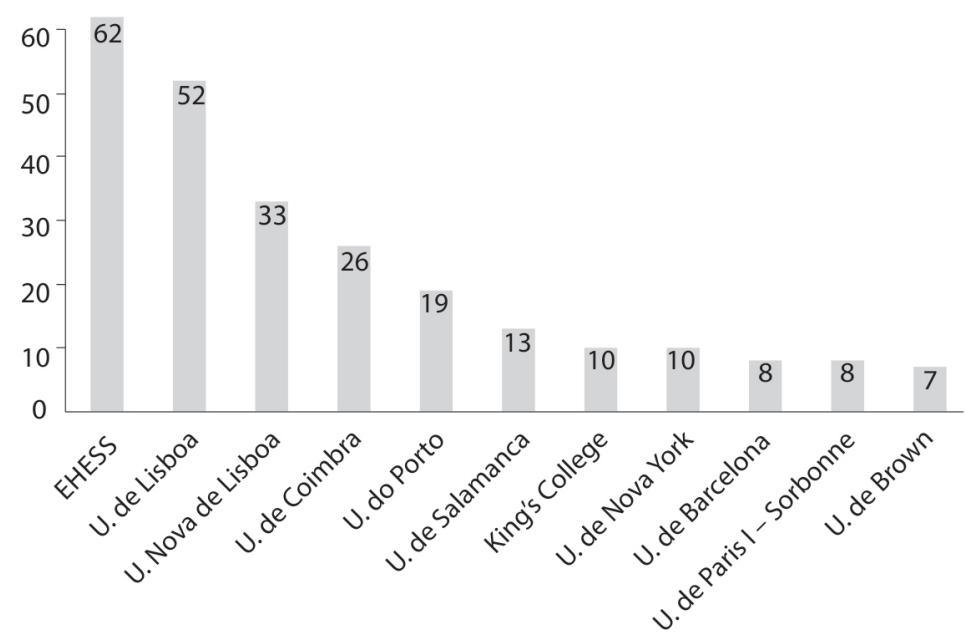

Figura 8: Dez principais instituições de destino de historiadores(as) bolsistas de pósdoutorado Capes, 1998-2017 (Fonte: GeoCapes)

Sobre as dez instituições listadas na Figura 8 incidem 241 registros ao longo desse período, o que corresponde ao total de $45 \%$ das anotações. Isso quer dizer, de forma aproximativa, 
que quase metade dos estágios ficou concentrada em dez instituições. Todas essas instituições pertencem aos cinco principais países de destino dos(as) historiadores(as) brasileiros(as). A École des Hautes Études en Sciences Sociales (EHESS) foi responsável sozinha por receber 11,6\% dos(as) estagiários(as). Se essa tradicional instituição fosse um país, ela teria sido o quarto destino mais importante. Chama também a atenção o fato de que quatro dessas instituições estejam situadas em duas cidades: Paris e Lisboa. Isso quer dizer que quase um(a) em cada três historiadores(as) brasileiros(as) que estagiaram no exterior poderia ser encontrado(a) em uma dessas duas cidades. Nos EUA, os/as estagiários(as) dispersaram-se por 23 universidades (número similar ao registrado na França), ao passo que em Portugal eles(as) se concentraram em 11 instituições. Registre-se ainda o fato de nenhuma instituição da América Latina figurar nessa lista.

\section{Doutorado sanduíche}

\section{Números gerais}

Façamos o mesmo tipo de exercício em relação às bolsas de doutorado sanduíche. Os limites que a análise impõe aqui são da mesma ordem daqueles que se apresentaram no caso anterior, relativos à forma anual (mas não individualizada) de registro da Capes. Há, todavia, uma vantagem nesse caso: é possível comparar o número de registros anuais de bolsas no exterior com o número de estudantes matriculados(as) em cursos de doutorado, de maneira geral e específica, considerando qualquer área do saber. Podemos, portanto, de um ponto de vista comparativo, obter uma série mais longa (Figura 9).

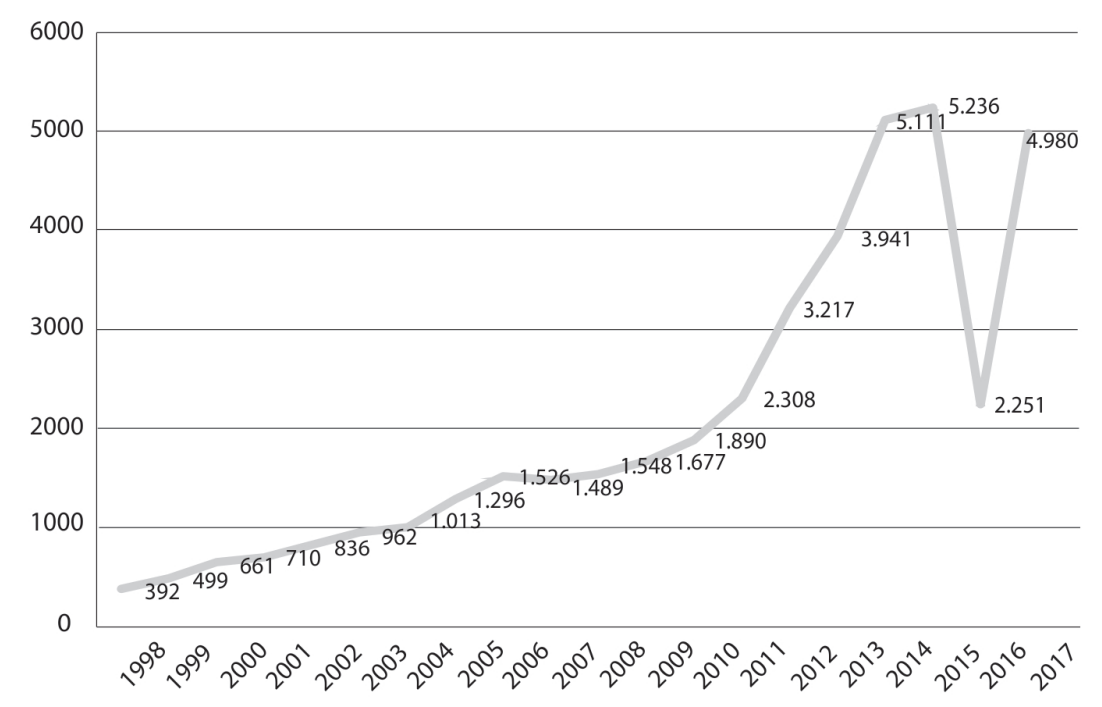

Figura 9: Número anual de estagiários(as) de doutorado sanduíche no exterior com bolsa Capes, 1998-2017 (Fonte: GeoCapes)

Entre 1998 e 2003, houve crescimento regular do número de bolsistas que realizaram doutorado sanduíche. Nos três anos seguintes, esse número aumentou significativamente, em torno de 50\%. A partir de 2003, a Capes deixou de oferecer bolsas de mestrado no exterior 
e passou a valorizar a realização do doutorado sanduíche como formação complementar no exterior (Capes, jul. 2011). Entre 2004 e 2006, novamente, registra-se ampliação de 50\% no número de bolsistas. Até 2005, havia duas portas de acesso às bolsas de doutorado sanduíche. A primeira, via Programa de Doutorado no País com Estágio no Exterior (PDEE), reservada exclusivamente para discentes de programas nota 5, 6 e 7, e cujas cotas de bolsa eram descentralizadas nas pró-reitorias das instituições de ensino superior. A segunda, via "balcão". No final de 2005, os/as estudantes de programas nota 4 foram incorporados(as) ao PDEE com o objetivo de ampliar a oferta de bolsas. A partir de 2006, as bolsas via "balcão" ficaram reservadas a discentes de programas nota 3 e de novos cursos de doutorado (Jacinto, 2005). Após uma queda em 2007, há elevação regular a partir do ano seguinte, alcançando 1.890 bolsistas em 2010, um ano antes da criação do CsF. Entre 2011 e 2015, registra-se crescimento exponencial do número de estagiários(as) no exterior, da ordem de 177\% em relação a 2010. Em meados de 2011, é preciso relembrar, a Capes lançou o Programa Institucional de Doutorado Sanduíche no Exterior (PDSE), que substituiu as duas portas de acesso às bolsas e suas regras. Seu objetivo era facilitar e ampliar o número de estagiários no exterior. A partir de então, estudantes pertencentes a qualquer curso de doutorado credenciado pela agência federal poderiam participar do programa. Mais importante: todo curso credenciado passaria, a partir de 2011, a dispor de duas cotas de bolsas, o que impulsionaria fortemente a realização de estágios a partir de então (Capes, 28 jun. 2011). Em 2016, em função da restrição orçamentária e da suspensão do edital de novas bolsas, assistiu-se a uma queda brutal do número de bolsistas. No ano seguinte, houve recomposição do orçamento do PDSE, e o número de registros retornou aos níveis de 2014 e 2015, quando aconteceu o ápice da oferta de bolsas por esse programa. Esse é um dado bastante interessante, sobretudo se lembrarmos que isso não ocorreu no caso analisado na primeira parte deste artigo. Ele indica, ao mesmo tempo, quais eram as prioridades da agência em sua política de internacionalização.

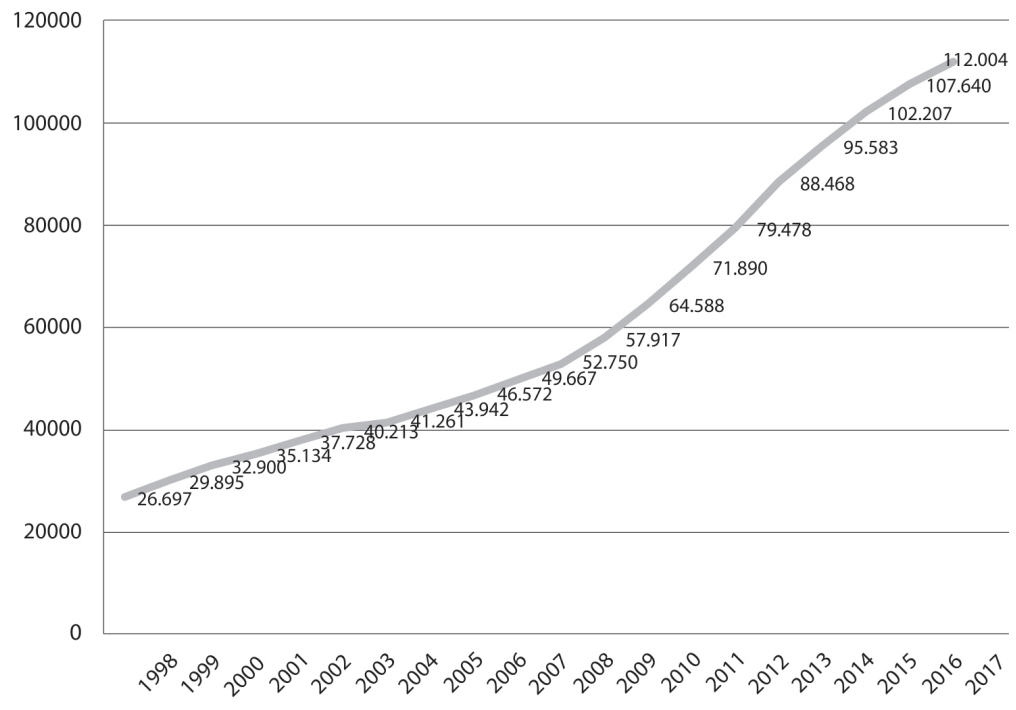

Figura 10: Número anual de estudantes matriculados(as) em cursos de doutorado no Brasil, 1998-2017 (Fonte: GeoCapes) 
Os dados sobre o crescimento anual do número de matrículas nos cursos de doutorado no país permitem definir um sólido parâmetro comparativo para avaliar o aumento da densidade de bolsas sanduíche durante esse período. Em quase duas décadas, o país saiu de 26.697 matrículas em 1998, para 112.004 matrículas em 2017, expansão da ordem de $320 \%$. Ao menos duas tendências podem ser observadas na Figura 10. Entre 1998 e 2008, o aumento anual do número de novas matrículas de doutorado no país ficou entre mil e 3 mil. A partir de 2009, portanto antes do novo PNPG, que iria prever como uma de suas metas a ampliação do acesso a esse nível de formação e o aumento da titulação de doutores no país, girou acima de 5 mil, com exceção do último ano da série.

A relação entre essas duas séries - registro anual de bolsistas em estágio no exterior e número anual de matrículas de doutorado -, representada na Figura 11, torna possível observar a porcentagem anual de estudantes brasileiros(as) que realizaram formação doutoral complementar no exterior.

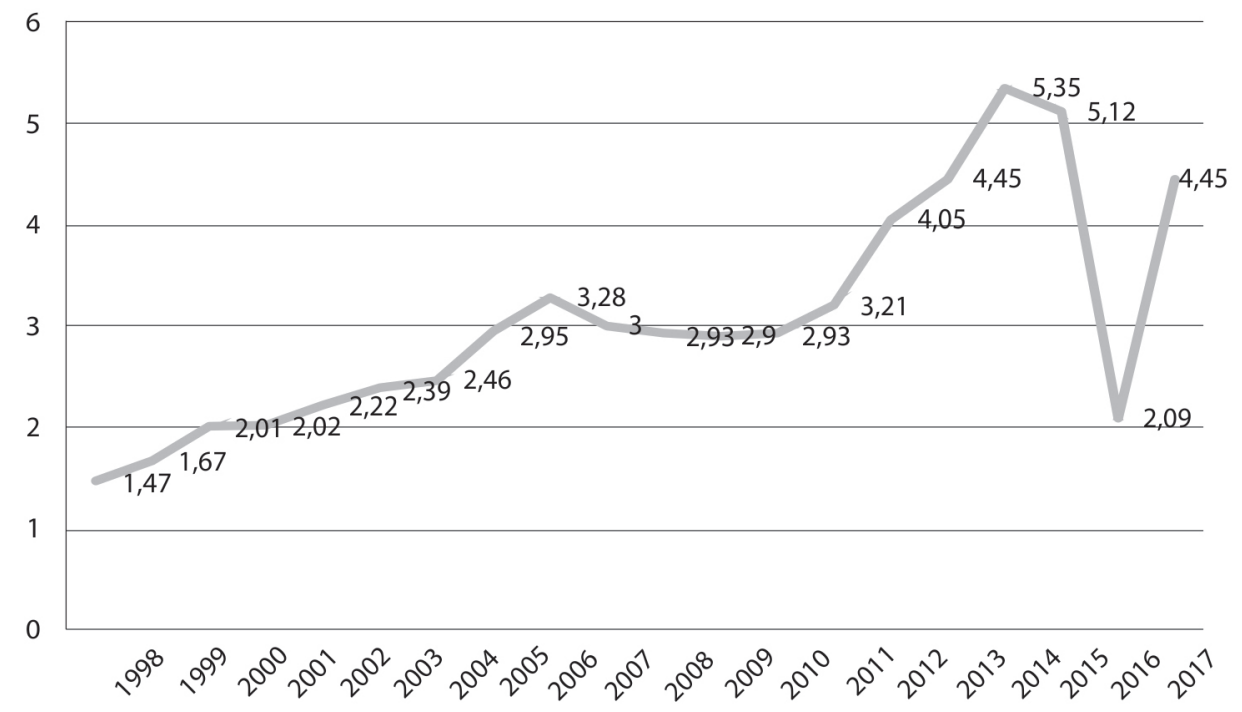

Figura 11: Percentual anual de doutorandos(as) brasileiros(as) no exterior, 1998-2017 (Fonte: GeoCapes)

Entre 1998 e 2004, de 1,5\% a 2,5\% dos(as) doutorandos(as) brasileiros(as) realizaram parte de sua formação no exterior com bolsa Capes. Entre 2005 e 2011, esse percentual se estabilizou num patamar um pouco mais levado, em torno de $3 \%$. Nos anos que se seguiram à criação do PDSE e à implementação do CsF, esse percentual cresceu significativamente, atingindo 5,35\% em 2014. Em 2016, regrediu aos níveis registrados no início dos anos 2000. Em 2017 houve importante recuperação dos investimentos no PDSE, e o percentual de bolsistas brasileiros(as) estagiando no exterior retornou aos níveis de 2013; portanto, aos altos níveis registrados ao longo do período e que correspondem aos dos anos de vigência do CsF. 


\section{Números na área de história}

Passemos agora ao número de registros anuais na área de história. Ao passo que o aumento do número de doutorandos(as) brasileiros(as) (de todas as áreas) ocorreu de forma regular entre 1998 e 2006, na área de história houve certa irregularidade (Figura 12). Até 2003, essa área manteve anualmente um número crescente de estagiários(as) no exterior, o que não se observou nos anos seguintes. Apenas em 2008 o número anual de registros superou aquele verificado em 2003, o que parece sugerir que a comunidade historiográfica ainda não tinha tomado plena consciência desse vetor de internacionalização. A partir de 2010, registrou-se uma tendência de crescimento desses números, que foram fortemente beneficiados pela criação do PDSE e do CsF. Em 2017, a área de história conseguiu recuperar parte importante das perdas registradas no ano anterior e posicionar-se um pouco acima dos níveis alcançados em 2013.

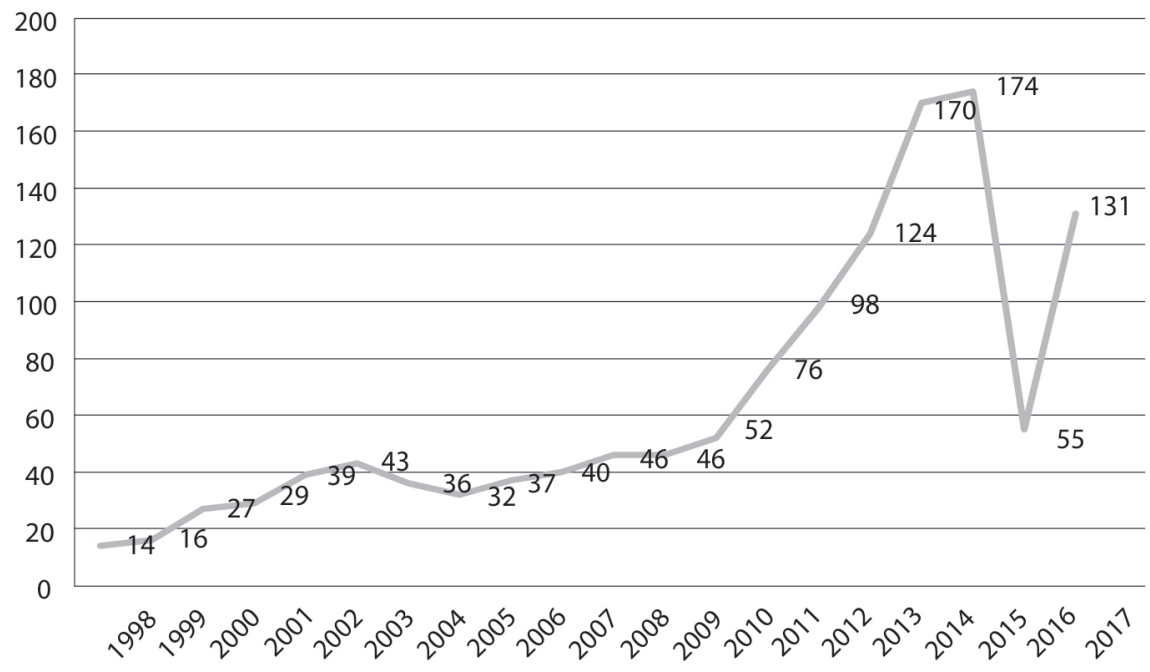

Figura 12: Número anual de doutorandos(as) da área de história com bolsa de doutorado sanduíche, 1998-2017 (Fonte: GeoCapes)

Entre 1998 e 2017, o número de estudantes de doutorado na área de história triplicou, saindo de 839 e alcançando 2.620 matrículas. Entre 1998 e 2001, foram criados cinco novos cursos de doutorado na área, impulsionando o número de novas matrículas. Até 2010, trienalmente, dois novos cursos foram criados, o que explica o crescimento regular do número de novas matrículas até o ano da avaliação trienal de 2010, quando a área de história atingiu o total de 25 cursos nesse nível. O grande salto ocorreu entre 2010 e 2017, quando 15 novos cursos de doutorado foram abertos, 13 deles entre 2010 e 2013. Isso permitiu que o número de doutorandos(as) em história no país aumentasse significativamente. Entre 2010 e 2017, o número de matrículas praticamente dobrou (Figura 13). 


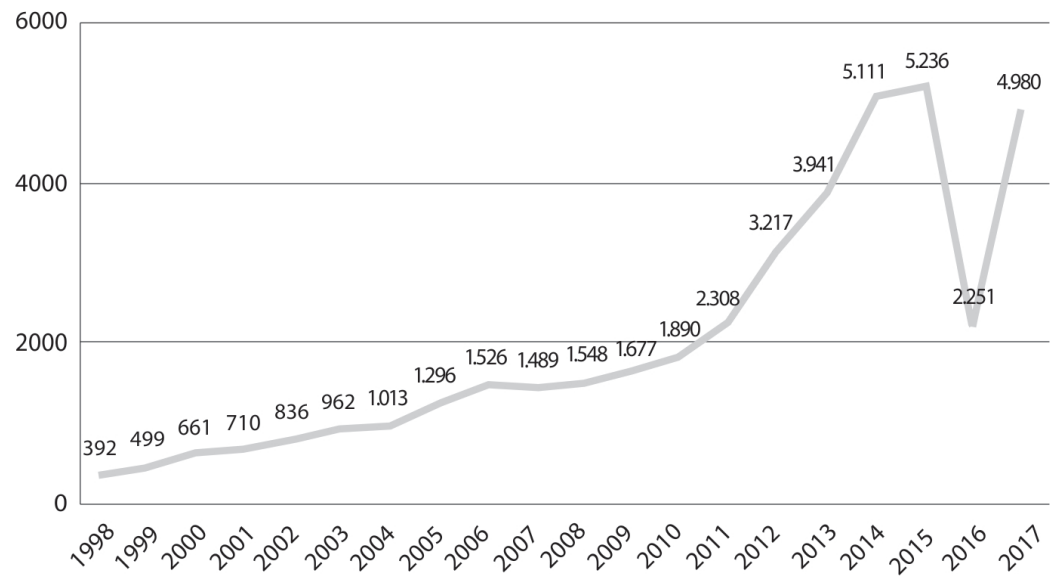

Figura 13: Número anual de estudantes matriculados(as) em cursos de doutorado em história no país, 1998 e 2017 (Fonte: GeoCapes)

A Figura 14 permite comparar a evolução do percentual de doutorandos(as) de todas as áreas e doutorandos(as) na área de história que estagiaram no exterior entre as quase duas décadas em análise. Com exceção de 2005 e 2006, o percentual de doutorandos(as) em história sempre foi maior do que o percentual de doutorandos(as) de todas as áreas. Entre 2004 e 2007, como vimos, o número de registros de bolsas na área de história no exterior foi inferior ao de 2003. Em função do crescimento do número de matrículas de doutorado na área de história, apenas em 2011 esse percentual ultrapassaria aquele registrado em 2003 e aumentaria significativamente nos anos seguintes em função do CsF. Em 2014 e 2015, quase $8 \%$ dos(as) doutorandos(as) em história do país realizaram estágio formativo no exterior. Será preciso avaliar, no futuro, os impactos dessa experiência formativa internacional na historiografia brasileira.

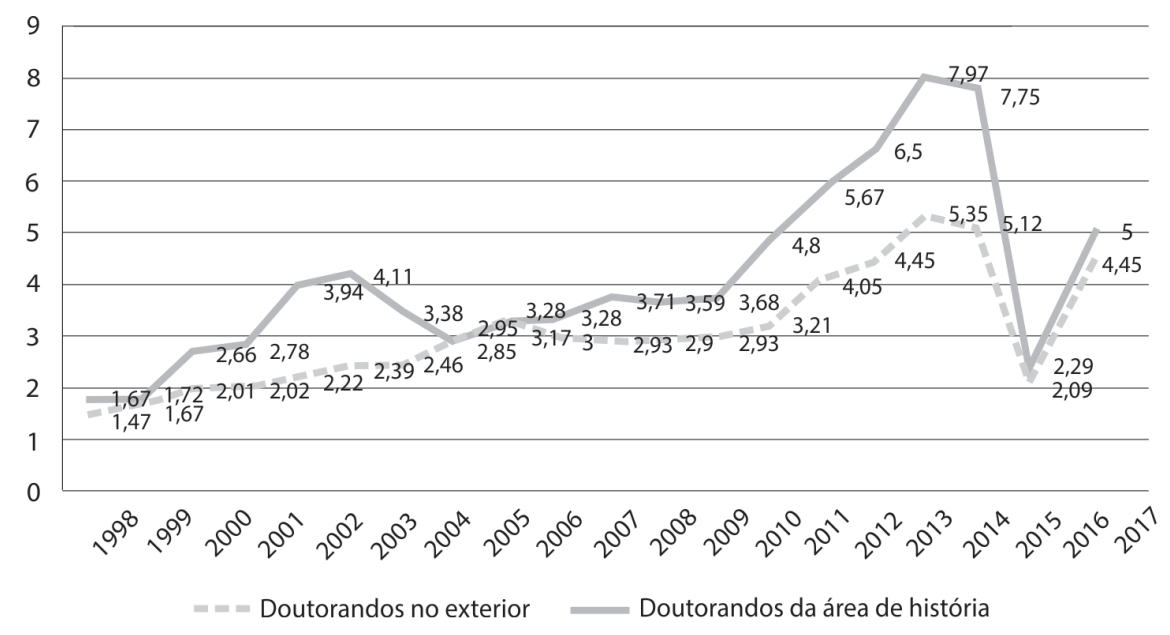

Figura 14: Proporção de todas as áreas e da área de história com bolsa de doutorado sanduíche da Capes no exterior, 1998-2017 (Fonte: GeoCapes) 
Poderíamos rapidamente nos voltar para nossa vizinhança epistemológica com o intuito de comparar a área de história com algumas áreas afins. Consideremos 2014, que contou com o maior número de bolsistas brasileiros(as) de doutorado no exterior. Nesse ano, como vimos, a área de história manteve quase $8 \%$ de seus doutorandos(as) no exterior. A de geografia manteve 4,36\%; a de educação, 5,16\%; a de sociologia, 6,44\%; a de letras, 7,37\%; a de antropologia/arqueologia, 10,52\%; e a de filosofia, 12,65\%.

Até 2008, história e filosofia mantinham no exterior percentuais muito semelhantes de doutorandos(as). A partir de então, a filosofia se descolou da história e ampliou significativamente esse percentual. Já a área de antropologia/arqueologia, desde o início da série, sempre manteve um percentual de estudantes superior ao de história. Interessante observar é que essas (filosofia e antropologia/arqueologia) são, entre as áreas que comparamos aqui, as duas menores em termos de quantidade de programas e pesquisadores(as). Do ponto de vista absoluto, portanto, elas receberam menos bolsas, mas do ponto de vista relativo, ocorre o oposto. Comparemos agora história e letras/ linguística. Entre 1998 e 2003, elas possuíam porcentagens bastante próximas. A partir de então e até 2010, a área de letras/linguística manteve-se acima da de história. A partir de 2011, a de história soube utilizar de maneira mais eficiente os novos recursos disponíveis e desde então manteve-se à frente da de letras/linguística. Já história e sociologia sempre figuraram, ao longo dessas quase duas décadas, muito próximas uma da outra. Apenas entre 2008 e 2010, a área de sociologia esteve um pouco acima da de história. Observese que, em 1998, a área de sociologia possuía um curso a mais de doutorado do que a de história. Nos dois triênios seguintes, o número de cursos de doutorado em história foi superior ao de sociologia. Isso se inverteu novamente entre 2007 e 2010. Isso se alterou durante os anos de expansão recente da ciência brasileira. Em 2010, a área de sociologia possuía 30 cursos de doutorado, e a de história, 25. Sete anos depois, em 2017, sociologia passou a contar com 32 cursos, e história, com 39. Finalmente, em relação à área de educação, cabe registrar que a área de história, ao longo desse período, sempre manteve um número muito maior de estagiários(as) no exterior. Isso também pode ser dito, excetuando-se o primeiro e o penúltimo ano da série, em relação à área de geografia, cuja expansão recente foi bastante significativa.

\section{Destinos no exterior}

Os dados apresentados na Tabela 2, como afirmamos inicialmente, não traduzem objetivamente a porcentagem de bolsistas em diferentes países nessas quase duas décadas, mas fornecem um número aproximativo, que nos permite avaliar os principais caminhos de circulação internacional de historiadores(as) brasileiros(as) em sua última etapa de formação.

Embora a mobilidade internacional dos(as) doutorandos(as) em história seja mais ampla e diversificada que a de seus professores(as) quando em pós-doutoramento, se considerarmos o número de países onde os estágios foram realizados, os mesmos tipos de orientações são observados nesse caso. O total de registros de bolsas sanduíches durante esse período dividese em trinta países, quase o dobro do registrado no caso do pós-doutoramento. Isso não deve sugerir, todavia, maior diversidade de destinos, pois observa-se aqui o mesmo tipo de 
concentração que se verifica na circulação de historiadores(as). Do total de registros, 54,2\% concentram-se em dois países: Portugal e França. Concentrados em apenas quatro países Portugal, França, EUA e Espanha - estão 75,4\%. A península ibérica é um destino importante dos(as) historiadores(as) em formação: 39\% dos estágios foram realizados nessa região. Se é verdade que houve um número maior de estagiários(as) na África, todos eles estiveram em apenas dois países. Se é verdade que há uma inserção maior e mais variada na América Latina, que há registros de estagiários(as) no Leste europeu, no Oriente Médio e mesmo na Ásia, trata-se de uma circulação bastante marginal, certamente, ligada aos objetos e temas individuais do trabalho de investigação das teses. ${ }^{10}$ Finalmente, a diversificação de destinos ocorreu muito recentemente e foi impulsionada pela ampliação do acesso ao financiamento desses estudos a partir de 2012 e a mudanças no próprio campo historiográfico, que se expandiu significativamente naquele período. Basta observarmos que a concentração do registro de bolsas em Portugal e na França, antes dessa expansão, era ainda maior. Quando se constata a grande quantidade de bolsas atribuídas para estágios nos EUA e na Espanha, por exemplo, não se deve deixar de considerar que a maioria delas foi concedida apenas nos últimos anos.

Tabela 2: Destinos dos(as) doutorandos(as) vinculados(as) à área de história no exterior, 1998-2017

\begin{tabular}{cc}
\hline País & $\%$ \\
\hline Portugal & 30,5 \\
França & 23,7 \\
EUA & 12,7 \\
Espanha & 8,5 \\
Itália & 5,1 \\
Inglaterra & 4,7 \\
Alemanha & 3,6 \\
Argentina & 3,3 \\
México & 2,1 \\
Canadá & 0,9 \\
Outros & $\mathbf{5}$ \\
\hline
\end{tabular}

Fonte: GeoCapes.

Como se vê, a circulação internacional de historiadores(as) brasileiros(as) em formação reproduz, em linhas gerais, aquela dos(as) historiadores(as) brasileiros(as) formados(as). Não surpreende, pois isso indica alguma solidez dos vínculos e algum enraizamento dos circuitos construídos inicialmente pelos(as) pesquisadores(as) e que servem, em seguida, como vetor de inserção internacional dos(as) jovens pesquisadores(as). E se o número de "pioneiros(as)" desbravando novos países e espaços de formação é em geral baixo, ele é, nesse nível, sem dúvida superior àquele que se verifica na ciência "estabelecida". Esses anos de expansão também corresponderam a uma diversificação maior da circulação de nossos(as) doutorandos(as). 
Por essa razão, é interessante observar a evolução do seu deslocamento no exterior, considerando os cinco países de maior incidência desses estágios.

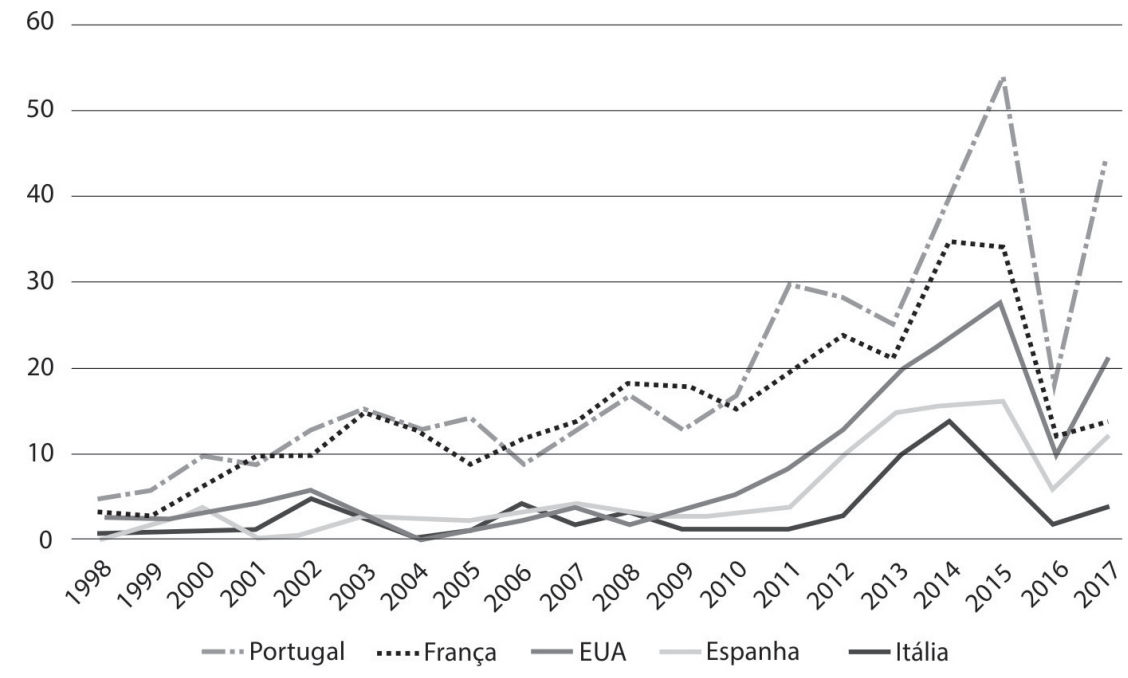

Figura 15: Movimento dos(as) historiadores(as) em formação complementar nos cinco principais destinos no exterior, 1998-2017 (Fonte: GeoCapes)

Como visto na Tabela 2, Itália e Inglaterra receberam praticamente o mesmo número de estagiários(as) durante esse período. A diferença é mínima. Elas invertem suas posições, portanto, em relação às bolsas de pós-doutorado, registrando-se ligeira alteração na composição dos cinco países mais procurados pelos(as) historiadores(as) brasileiros(as) em formação. Diferentemente do que se observava no caso dos pós-doutoramentos, desde praticamente o início da série há claro descolamento de Portugal e França dos demais países de destinação, sendo, incontestavelmente os dois principais destinos dos(as) doutorandos(as) brasileiros(as). Apenas em 2017 os EUA ocuparam o segundo posto. Até 2011, esses dois países alternavam-se como principais destinos dos(as) estudantes brasileiros(as). É apenas a partir de então que Portugal se consolida na primeira posição. ${ }^{11}$

A Figura 15 indica, no que concerne à França, um mesmo tipo de movimento que se identificou no caso dos estágios pós-doutorais. A diferença aqui é que os EUA passam a ocupar o segundo posto, e a Espanha praticamente empata com a França. Seria isso uma tendência ou apenas um dado localizado? Os três outros países seguiram sempre bastante próximos. É apenas a partir de 2009 que parece haver um descolamento entre eles, que se consolidaria nos anos seguintes. Também é preciso considerar até que ponto a queda da exigência de proficiência em língua estrangeira, com a implementação do PDSE, favoreceu a promoção de destinos como os EUA, por exemplo. Essa nunca foi, como se observa, uma barreira no caso francês.

Poderíamos, finalmente, comparar esse movimento da área de história com o de bolsistas de doutorado sanduíche de todas as áreas. Embora haja pequenas diferenças, não há grandes surpresas. Quando se consideram as bolsas de doutorado sanduíche concedidas 
pela Capes para todas as áreas, entre 1998 e 2017, observa-se que EUA e França, na maior parte do tempo, partilharam o posto de principal destino dos(as) estagiários(as). Entre 1998 e 2001, os EUA ocuparam a frente dessa preferência. Já em 2002, a França tomou esse lugar e aí permaneceu por quase uma década, até 2011. No primeiro ano de vigência do CsF, os EUA recuperaram a primeira posição, que foi mantida até 2017. Entre 2012 e 2017, a França só não ocuparia a segunda posição em 2015 e 2017, quando seria desbancada por Portugal. De um lado, fica patente que a política de indução do governo Dilma Roussef atuou claramente nessa reconfiguração geográfica. De outro, não se deve considerar que houve queda na procura por estágios ou diminuição no interesse pela França. A procura por estágios nesse país apenas não cresceu na mesma proporção que a ocorrida em países como EUA e Portugal. A questão seria justamente pensar esse crescimento menor em relação a esses dois outros países.

O caso de Portugal é interessante. Entre 1998 e 2002, ocupou sempre a quarta posição no destino dos(as) bolsistas brasileiros(as). A partir dos anos seguintes, Portugal passou a ocupar o posto de terceiro destino preferencial dos(as) doutorandos(as) brasileiros(as), do qual só saiu em 2015 e 2017, como dissemos há pouco, para alcançar a segunda posição. O caso da importância de Portugal na geografia internacional dos(as) estudantes brasileiros(as) explica-se por razões ao mesmo tempo históricas e linguísticas, e relembra ao menos dois outros exemplos semelhantes: as presenças maciças de estudantes africanos(as) na França e de latino-americanos(as) na Espanha (Unesco, 2019, p.98). Seria preciso considerar, da mesma forma, até que ponto o esforço português de recrutamento de estudantes brasileiros(as) nos últimos anos pesou nesse aspecto.

A Espanha, que entre 1998 e 2004 oscilou entre a quarta e a sexta posição, a partir de 2005 tornou-se e se manteve como quarto principal destino dos(as) doutorandos(as) brasileiros(as) em estágio sanduíche. Entre 1998 e 2001, o Reino Unido ocupou a terceira posição nessa lista. No ano seguinte, ficou em sexto, e, em 2003, passou ao quinto posto. Entre 2003 e 2012, permaneceria na sexta posição, e apenas em 2013 recuperaria esse quinto lugar, no qual permaneceria até o final da série em análise. Finalmente, o último país que figurou na lista dos cinco principais destinos dos(as) doutorandos(as) brasileiros foi a Alemanha. Em 2001, ela se tornou o quarto principal destino, e, no ano seguinte, chegou mesmo a ocupar a terceira posição. Em 2003, esteve em sexto e no ano seguinte, voltou à quarta posição. Entre 2005 e 2012, manteve-se na quinta posição, que cederia ao Reino Unido até o final da série em análise.

Não há diferença relevante, portanto, entre a geografia da mobilidade internacional da área de história e da ciência brasileira em formação. Numa e noutra são os mesmos quatro países que encabeçam a lista dos principais destinos da ciência brasileira em formação, em ambas a França ocupando o segundo posto; a Espanha, o quarto; e Portugal e os EUA se alternando na primeira posição. A única e mínima diferença se observa na quinta posição. Em todas as áreas, a disputa por ela ocorre entre o Reino Unido e a Alemanha, ao passo que na de história a Itália ganha preferência. O que não deixa de ser curioso, se pensarmos que a Alemanha, cuja importância epistemológica e disciplinar para a história é inquestionável, ocupa apenas a sétima posição nessa lista, praticamente empatada com a Argentina. 


\section{Instituições de destino}

Quase metade dos(as) discentes brasileiros(as) na área de história estagiaram em apenas dez instituições no exterior ou, sendo mais precisos, 45,1\% dos registros do período correspondem a esses dez endereços, exatamente a mesma porcentagem observada em nossa análise da Figura 8, relativa às instituições de estadia dos(as) historiadores(as) brasileiros(as). A EHESS foi responsável por atrair um número considerável de doutorandos(as) brasileiros(as) no período, 11,6\%, mesmo percentual que observamos em nossa análise da Figura 8. Observa-se concentração de bolsistas em poucas instituições de dois países: 40\% deles se distribuíram em apenas sete endereços de dois países, França e Portugal. Quase 1/3 deles aterrissou em Paris ou Lisboa.

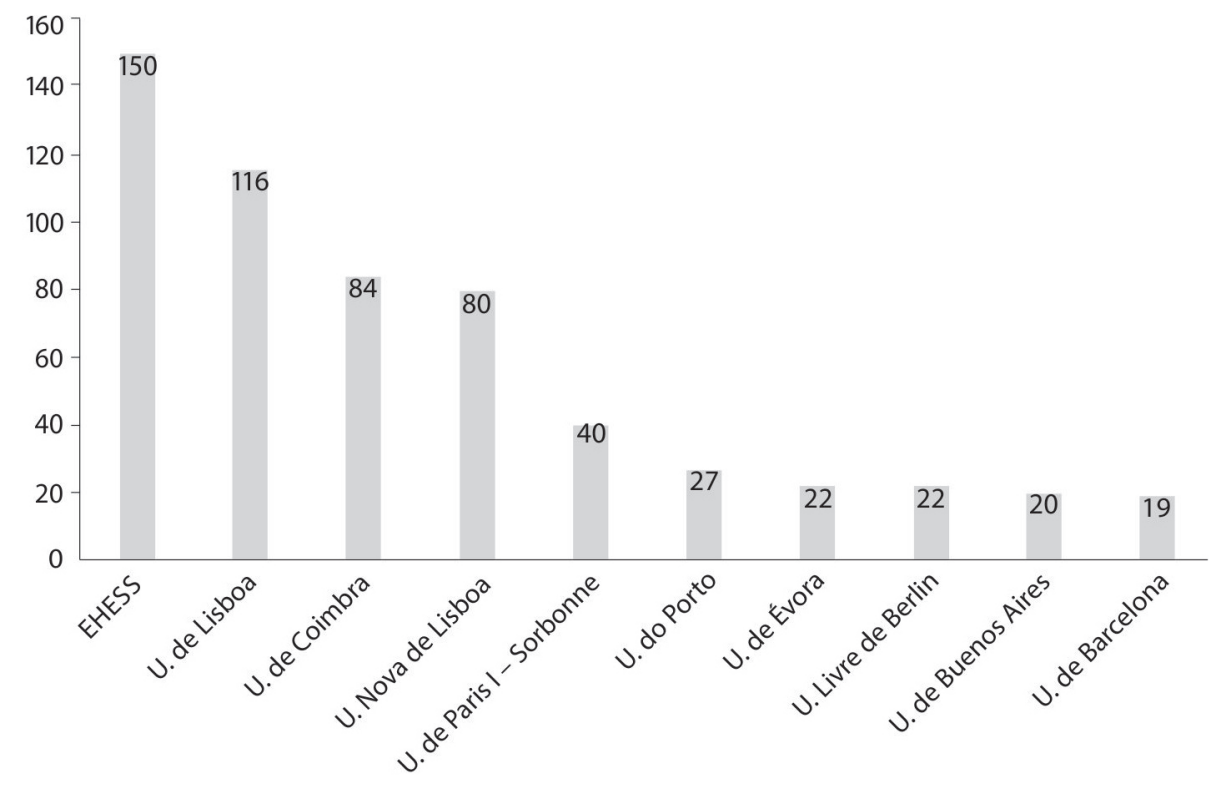

Figura 16: Dez principais instituições de destino de doutorado sanduíche Capes, área de história, 1998-2017 (Fonte: GeoCapes)

A concentração da circulação de doutorandos(as) brasileiros(as) em Portugal é bastante significativa: um(a) em cada quatro deles(as) estagiou nesse país. Surpreende nessa lista o caso da Universidade de Évora. Apenas recentemente ela despontou nessa geografia internacional da historiografia brasileira. O primeiro estagiário(a) registrado(a) nessa instituição data de 2011; todavia, mais da metade dos registros de estágios nessa universidade datam dos três últimos anos da série (2015-2017). Todas as outras instituições portuguesas arroladas na Figura 16 receberam doutorandos(as) desde os primeiros anos da série. Um dado que também chama a atenção diz respeito à Universidade de Coimbra, que concentra quase $36 \%$ dos seus registros nos quatro últimos anos da série. Apenas em 2017, ela recebeu 14 doutorandos(as) em história.

O caso da Universidade Livre de Berlim também é interessante. Considerando a série analisada, apenas em 2013 ela recebeu o(a) primeiro(a) estudante brasileiro(a) para um 
estágio de doutorado sanduíche. Quase 64\% dos estagiários nessa instituição foram financiados por programas específicos relacionados a acordos entre a Capes e o Deutscher Akademischer Austauschdienst (DAAD). O que nos leva a considerar que a exigência de proficiência, neste caso, pode ter funcionado como uma barreira para a apresentação de candidaturas - os bolsistas Capes/DAAD recebiam treinamento, antes do início do estágio, em língua alemã. ${ }^{12}$

Em relação à Universidade de Buenos Aires, já há um registro de estágio em 2000, mas a frequência de estagiários(as) nessa instituição tornou-se regular apenas a partir de 2009. Mais da metade dos registros anuais de estágio nessa instituição datam, todavia, dos últimos três anos da série. ${ }^{13}$

Quando se comparam as Figuras 16 e 8, é difícil não deixar de registrar suas semelhanças. Sete das dez instituições aparecem nos dois gráficos: EHESS e as universidades de Lisboa, Nova de Lisboa, de Coimbra, do Porto, de Paris I e de Barcelona. Isso indica clara reprodução no nível de formação doutoral das relações e vínculos acadêmicos já existentes entre os/ as historiadores(as) e orientadores(as) formados(as). Não há, como se observa, nenhuma instituição norte-americana ou anglófona no último gráfico, indicando baixa concentração institucional de bolsistas nesses países, que se distribuem por vários endereços acadêmicos. Sai da Figura 16 uma instituição espanhola (Universidade de Salamanca) e entra uma portuguesa (Universidade de Évora). Duas instituições de dois diferentes países ocupam aqui o lugar das instituições anglo-americanas: uma latino-americana, a Universidade de Buenos Aires, e outra europeia, a Universidade Livre de Berlim.

\section{Considerações finais}

Entre 2004 e 2010, a média de estagiários(as) de pós-doutorado da área de história no exterior esteve sempre muito próxima da média geral. Foi apenas a partir de 2011 que ocorreu um descolamento dessas duas médias, favorável à área de história. Entre 1998 e 2017, vimos que esses(as) estagiários(as) concentraram-se em poucos destinos, quase metade deles(as) em apenas dois países, Portugal e França, e quase quatro em cada cinco bolsistas estiveram em apenas quatro países: Portugal, França, EUA e Espanha. Foi possível também reconstituir a evolução da configuração anual desse circuito internacional ao longo de quase duas décadas. Finalmente, identificamos as dez principais instituições no exterior que receberam esses(as) estagiários(as) e que concentraram quase metade de todos(as) os/ as bolsistas brasileiros(as).

Entre 1998 e 2017, a média de doutorandos(as) em história estagiando no exterior foi, na maior parte do tempo, superior à média geral, com destaque para o biênio 2014-2015, quando a área manteve quase $8 \%$ de seus discentes no exterior. Uma rápida comparação dessa área com outras pertencentes ao arco das humanidades permitiu observar os níveis de inserção de cada uma delas. O destino desses(as) estudantes foi pouco variado: dois/ duas em cada quatro doutorandos(as) foram para Portugal ou França; três em cada quatro estiveram em apenas quatro países: Portugal, França, EUA e Espanha. Desde o início da série em tela, Portugal e França ocuparam incontestavelmente as preferências dos(as) historiadores(as) em formação. Entre 1998 e 2009, EUA, Espanha e Itália seguiam lado a 
lado na lista de destino preferencial desses(as) doutorandos(as). A partir de 2009, houve descolamento entre eles, e os EUA - que tomariam o lugar da França em 2017 - passaram a ocupar a terceira posição, seguido de Espanha e Itália. Finalmente, vimos que metade desses(as) doutorandos(as), ao longo desse período, ficaram alojados(as) em apenas dez instituições científicas.

A geografia dessa mobilidade historiográfica brasileira em formação e formada, como se viu, coincide em seus grandes traços, suscitando um circuito intelectual e profissional em torno de quatro países. Paris, Lisboa: as capitais internacionais da historiografia brasileira. Um(a) em cada três estagiários(as) de pós-doutorado e doutorandos(as) brasileiros(as) no exterior estagiou nessas cidades. À frente nas duas listas, a EHESS, uma espécie de espaço de legitimação da competência e da autoridade epistemológica da historiografia brasileira. A importância do boulevard Raspail para nossa historiografia sugere, ao mesmo tempo, qual o tipo de história valorizada, nesse caso, pelos(as) historiadores(as) brasileiros(s) em trânsito nesses quase 20 anos. Todavia, para afirmar isso com algum grau de profundidade, outros materiais teriam que ter sido consultados, e outras perguntas, formuladas. Por outro lado, isso permite compreender, ao menos em parte, uma das razões do peso e da importância dessa historiografia em nosso país. Não devemos buscar compreender esse peso e essa importância apenas como resultado de uma tradição longínqua, cujas origens poderíamos fazer recuar à importância do positivismo no Brasil no século XIX. Devemos também levar em consideração as condições institucionais e político-científicas de reprodução teórica do campo historiográfico. Esse é um dado interessante, pois mostra como a forte presença da historiografia francesa está indissociavelmente ligada a bases materiais bastante concretas e não apenas à força de suas ideias inovadoras.

Será preciso observar a evolução, nos próximos anos, da mobilidade internacional docente e discente nessa área para observar se algumas tendências registradas nos últimos anos das séries analisadas, como aquela de anglo-americanização, confirmam-se ou não, se são de fato tendências ou apenas movimentos localizados.

Se pudemos falar em uma geografia dessa mobilidade, com circuitos e pontos fixos que estruturam o tráfego internacional de docentes e discentes, não deixa de ser interessante sublinhar uma clara tendência, observada ao longo desses quase vinte anos, de desconcentração e diversificação dos destinos no exterior. Em 1998, por exemplo, os/as bolsistas de doutorado sanduíche da área de história financiados pela Capes encontravam-se distribuídos em cinco países. Quinze anos depois, em 2013, eles podiam ser encontrados em 17 países. Sem dúvida, essas desconcentração e diversificação ocorreram concomitantemente ao aumento da oferta de cursos de doutorado, à ampliação de vagas no país e à forte ampliação do financiamento desse tipo de atividade, sobretudo, a partir de 2011. Será interessante observar, nos próximos anos, se esses pontos fixos manterão suas posições nesse circuito internacional ou as cederão a esses novos espaços e instituições de formação e pesquisa.

Da mesma forma, será importante observar como ficará doravante a posição de Portugal na mobilidade de historiadores(as) brasileiros(as). Nos últimos anos, as políticas científicas voltadas para a circulação e inserção internacional promovidas pelo Estado brasileiro vêm, em alguma medida, buscando limitar os vínculos da ciência brasileira com a portuguesa. 
Assistiu-se a isso no caso da circulação dos bolsistas de graduação no CsF. Mais recentemente, isso também se observou com a exigência de proficiência em língua inglesa para a realização de estágios doutorais em Portugal. Esse tipo de medida sugere que há discentes que apenas optam pelo estágio nesse país em função de sua inabilidade linguística. Há pouco, no âmbito do Programa Institucional de Internacionalização (Capes-Print), Portugal foi excluído do conjunto de países prioritários para ações de internacionalização. O edital previa que 70\% dos recursos fossem empregados em ações com 26 países predefinidos. Tratava-se de reforçar a relação com os "países com os quais a cooperação científica e acadêmica com o Brasil tem se mostrado mais efetiva" (Capes, 2 fev. 2018). Ora, Portugal é inquestionavelmente um dos principais portos de desembarque da ciência brasileira, e não há dúvidas da efetividade da cooperação com o Brasil. É preciso entender o que se define aí por efetividade. Certamente, não é o histórico da relação, sua importância e seus frutos. O que importa e define a efetividade é o impacto internacional que a ciência produzida num determinado país possui. Com isso, não estamos questionando a legitimidade da agência e das orientações de suas políticas de mobilidade internacional, mas apenas destacando que essa circulação acadêmica e a geografia que seus traços configuram não devem ser vistas apenas como resultantes do esforço individual, isolado e espontâneo de pesquisadores(as). Essa agência, ao mesmo tempo que, por meios de acordos específicos com determinados países, destrói barreiras, constrói e promove certos caminhos para a mobilidade internacional, controla determinados fluxos e muitas vezes erige fronteiras limitando a circulação para alguns destinos. Toda política estatal de brain circulation pressupõe em alguma medida uma polícia e um controle das fronteiras epistêmicas. A geografia da mobilidade científica internacional não é espontânea.

E não deixa de ser interessante observar que a geografia internacional da mobilidade historiográfica brasileira financiada pela Capes é formada praticamente pelos mesmos traços que delimitam a geografia geral da ciência brasileira. Esses números nos mostram, gostaríamos de insistir uma última vez, que os/as pesquisadores(as) brasileiros(as) da área de história, formados(as) e em formação, circulam pelos mesmos lugares que outros(as) cientistas brasileiros(as): EUA, França, Portugal e Espanha. Não são razões arquivísticas que justificam e explicam as estadias de doutorandos(as) brasileiros(as) em história em Portugal - isso talvez possa apenas ajudar a explicar por que esse país, nessa área, encabeça a lista. Da mesma forma, não são apenas as razões teóricas, metodológicas ou uma suposta influência da historiografia francesa que explicam o peso e justificam a atração de jovens doutorandos(as) ao país dos Annales. A área de história não destoa, nesse sentido, da ciência brasileira em geral. Ela se inscreve e participa de um movimento mais geral de circulação internacional da ciência nacional.

\section{AGRADECIMENTOS}

Agradecemos aos/às pareceristas a leitura atenta e as excelentes sugestões para o aperfeiçoamento do artigo e a continuidade da pesquisa. 


\section{NOTAS}

${ }^{1}$ A base de Dados Abertos presente na Plataforma Sucupira é resultado do preenchimento anual do ColetaCapes por parte dos coordenadores dos programas de pós-graduação stricto sensu existentes no país. O Coleta é o instrumento construído pela Capes para capturar informações anuais sobre os programas de pós-graduação, que são tratadas e utilizadas nas avaliações periódicas da agência. Consultamos a planilha Cursos da pós-graduação stricto sensu no Brasil. Ano base: 2018. Disponível em: https://dadosabertos.capes.gov. br/dataset/2017-a-2020-cursos-da-pos-graduacao-stricto-sensu-no-brasil/resource/ab604782-71f6-45eb-9762f95b6ad7c194. Acesso em: 14 mai. 2020. É importante observar que os cursos de pós-graduação encontrados na planilha são os que foram criados antes de 1965 e que estavam em funcionamento em 2018. Logo, podem ter existido outros cursos antes de 1965 e que foram encerrados, não constando da base de dados de 2018 .

${ }^{2}$ GeoCapes é uma ferramenta de dados georreferencial construída pela Capes para divulgar informações estatísticas sobre as ações da agência, que envolvem a concessão de bolsas e o financiamento dos programas de pós-graduação no país. O endereço da ferramenta é https://geocapes.capes.gov.br/geocapes/.

${ }^{3}$ Sobre a história das duas agências federais, que permite compreender a importância das décadas de 1940 e 1950 para a ciência e a pós-graduação brasileiras, ver, entre outros, Ferreira, Moreira (2002); Capes (jul. 2011); Kornis (2001).

${ }^{4}$ A partir de 2009, com o objetivo de diferenciar o recém-titulado e o doutor sênior (com pelo menos oito anos de titulação) e de separar as inscrições de candidatos com esses diferentes perfis em seleções distintas, a Capes criou o "Programa de Estudos para Estágio Sênior no Exterior". Em nossa análise não consideramos essa distinção, de modo a ampliar a série histórica de dados a esse respeito.

${ }^{5}$ O Programa de Apoio a Planos de Reestruturação e Expansão das Universidades Federais foi instituído em 2007 como parte do Plano de Desenvolvimento da Educação (PDE), também denominado PAC da Educação. Ele previa, para o prazo de cincos anos, recursos da ordem de 7 bilhões de reais a serem investidos na expansão das vagas no ensino superior público, particularmente com a abertura de cursos no período noturno e na infraestrutura das instituições federais de ensino superior (Ifes). Como contrapartidas, as Ifes deveriam elevar a taxa de conclusão de seus cursos e ampliar a relação professor/aluno.

${ }^{6}$ Para uma avaliação dos resultados do CsF, ver, entre outros: Macmanus, Nobre (2017); Coelho, Manços (2017).

${ }^{7}$ Coelho e Manços (2017, p.68-69) determinaram o tamanho desse benefício imprevisto.

${ }^{8}$ Em fevereiro de 2019, no momento em que estávamos analisando esses dados, a Capes ainda não havia disponibilizado as informações a esse respeito sobre 2017.

${ }^{9}$ As engenharias concentram fortemente a primazia no número de bolsas recebidas (Capes, jul. 2011, p.47).

${ }^{10}$ Eis os países e o número de registros da classificação "Outros" da Tabela 2: Moçambique e Uruguai, 9; Chile, 8; Israel, 6; Bélgica e Cuba, 4; Holanda e Irlanda, 3; Bolívia, Escócia, Equador, Paraguai, Áustria e Colômbia, 2; Angola, Armênia, Eslováquia, Polônia, Suíça e Venezuela, 1.

${ }^{11} \mathrm{O}$ governo brasileiro rapidamente reconheceu que, em função do baixo domínio de língua estrangeira dos estudantes de graduação, havia uma forte tendência de busca por estágios em Portugal. Já em 2012, estudantes de graduação selecionados para estagiarem em Portugal foram realocados em outras universidades estrangeiras, e até o encerramento da primeira etapa do programa, em 2014, Portugal deixou de figurar entre os países da lista de destinos para a realização de graduação sanduíche. A justificativa era de que o programa também buscava o aperfeiçoamento da língua estrangeira. Isso mostra como o governo dirigiu claramente o fluxo discente para países de língua inglesa (Borges, Garcia-Filice, 2016, p.86). Esse tipo de barreira não ocorreu nas seleções de doutorado sanduíche. Ao mesmo tempo, os candidatos do PDSE ficaram liberados, a partir de 2011, de apresentar certificação de proficiência em língua estrangeira (Toefl etc.), bastando que o supervisor estrangeiro, em sua carta de aceite, indicasse que o domínio e a compreensão da língua estrangeira do candidato eram suficientes para a realização do estágio. No final de 2017, a Capes lançou um novo edital (n.47/2017) para candidaturas ao PDSE no qual tornava a exigência de proficiência obrigatória e definia quais certificados e suas respectivas pontuações e notas seriam aceitos de acordo com os diferentes países. Para os países de língua portuguesa, passou a prever a exigência de certificado de proficiência em língua inglesa, certamente, como forma de restringir os estágios em Portugal.

${ }^{12}$ No edital do PDSE de 2017, a Capes, inicialmente pensando apenas na Alemanha, definiu que os/as estagiários(as) brasileiros(as) destinação a esse país poderiam apresentar certificado de proficiência em inglês. Num segundo momento, definiu que a certificação da língua inglesa poderia ser aceita para qualquer país de destino. Trata-se de importante reorientação em relação a uma política linguístico-científica (Capes, 27 dez. 2017). 
${ }^{13}$ Apenas a título de informação, listamos as instituições que receberam ao menos dez estagiários(as) durante o período em estudo: Universidade de Salamanca (18 estudantes), Complutense de Madrid (17), Universidade de Maryland (14), Unam (14), Universidade de Stanford (12), Universidade de Princeton (11), Sorbonne Nouvelle - Paris III (11), King's College (11), Universidade de Sevilha (10) e Universidade Georgetown (10).

\section{REFERÊNCIAS}

BORGES, Rovênia Amorim; GARCIA-FILICE, Renísia Cristina. A língua inglesa no Programa Ciência sem Fronteiras: paradoxos na política de internacionalização. Interfaces Brasil/Canadá, v.16, n.1, p.72-101, 2016.

BRISSON, Thomas. Le rayonemment déclinant de la pensée française? In: Charle, Christophe; Jeanpierre, Laurent (org.). La vie intelectuelle en France, de 1914 à nos jours. v.2. Paris: Seuil, 2016. p.779-802.

CAPES, Coordenação de Aperfeiçoamento de Pessoal de Nível Superior. Anexo I: Relação dos países parceiros. Alterado. Diário Oficial da União, Seção 3, p.23, 2 fev. 2018.

CAPES, Coordenação de Aperfeiçoamento de Pessoal de Nível Superior. Edital de Retificação PDSE: Edital de seleção 47/2017. Brasília, 27 dez. 2017.

CAPES, Coordenação de Aperfeiçoamento de Pessoal de Nível Superior. Capes 60 anos: revista comemorativa. [Brasília]: Acessoria de Comunicação da Capes, jul. 2011.

CAPES, Coordenação de Aperfeiçoamento de Pessoal de Nível Superior. Portaria n.96, de 27 de junho de 2011. Brasília, Diário Oficial da União, n.122, p.9, 28 jun. 2011.

CAPES, Coordenação de Aperfeiçoamento de Pessoal de Nível Superior. Plano Nacional de PósGraduação: PNPG 2011-2020. 2v. Brasília: Capes, 2010. Disponível em: https://www.capes.gov.br/ images/stories/download/Livros-PNPG-VolumeI-Mont.pdf. Acesso em: 10 jan. 2020.

CAPES, Coordenação de Aperfeiçoamento de Pessoal de Nível Superior. Plano Nacional de Pós-Graduação (PNPG), 2005-2010. Brasília: Capes, 2004. Disponível em: https://www. capes.gov.br/images/stories/download/editais/ PNPG_2005_2010.pdf. Acesso em: 10 jan. 2020.

CAPES, Coordenação de Aperfeiçoamento de Pessoal de Nível Superior. Portaria n.068. Brasília, 3 ago. 2004.

CAPES, Coordenação de Aperfeiçoamento de Pessoal de Nível Superior. II PNPG: Plano Nacional de Pós-Graduação, 1982-1985, s.d.-a.
Disponível em: https://www.capes.gov.br/ images/stories/download/editais/II_PNPG.pdf Acesso em: 10 jan. 2020.

CAPES, Coordenação de Aperfeiçoamento de Pessoal de Nível Superior. III PNPG: Plano Nacional de Pós-Graduação, 1986-1989, s.d.-b. Disponível em: https://www.capes.gov.br/ images/stories/download/editais/III_PNPG.pdf. Acesso em: 10 jan. 2020.

CAPES, Coordenação de Aperfeiçoamento de Pessoal de Nível Superior; CNPq, Conselho Nacional de Desenvolvimento Científico e Tecnológico. Ciência sem Fronteiras: um programa especial de mobilidade internacional em ciência, tecnologia e inovação. Brasília: MEC, MCTI, 2011.

CFE, Conselho Federal de Educação. Parecer n.977/65 da Câmara de Ensino Superior (CES) do Conselho Federal de Educação (CFE), aprovado em 3 de dezembro de 1965, 1965. Disponível em: https://www.capes.gov.br/images/stories/ download/legislacao/Parecer_CESU_977_1965. pdf. Acesso em: 14 maio 2020.

CHAVES, Gérlia Maria Nogueira. As bolsas de graduação-sanduíche do Programa Ciência sem Fronteiras: uma análise de suas implicações educacionais. Dissertação (Mestrado em Educação) - Universidade Católica de Brasília, Brasília, 2015.

CLOSS, Darcy. Entrevista concedida a Marieta de Moraes Ferreira e Regina da Luz Moreira em 8 de junho de 2001. In: Ferreira, Marieta de Moraes; Moreira, Regina da Luz (org.). Capes, 50 anos. Brasília: Capes, 2002.

COELHO, Fernando de Souza; MANÇOS, Guilherme de Rosso. Internacionalização da ciência brasileira: subsídios para avaliação do programa Ciência sem Fronteiras. Revista Brasileira de Políticas Públicas e Internacionais, v.2, n.2, p.52-82, 2017.

FERREIRA, Marieta de Moraes; MOREIRA, Regina da Luz (org.). Capes, 50 anos. Brasília: Capes, 2002.

HEILBRON, Johan. Toward a sociology of translation: book translations as a cultural world-system. European Journal of Social Theory, v.2, n.4, p.429-444, 1999. 
JACINTO, Sônia. Capes altera programa de doutorado sanduíche no exterior. Brasília, 2005. Disponível em: https://www.capes.gov.br/salade-imprensa/noticias/1366-blank-79190665. Acesso em: 26 ago. 2019.

KORNIS, Mônica. Conselho Nacional de Desenvolvimento Científico e Tecnológico (CNPq). In: Abreu, Alzira Alves de et al. (coord.). Dicionário histórico-biográfico brasileiro pós-1930. Ed. rev. e atual. Rio de Janeiro: Editora FGV, CPDOC, 2001. p.1549-1551.

LOMBAS, Maria Luiza de Santana. A mobilidade internacional acadêmica: características de percursos de pesquisadores brasileiros. Sociologias, ano 19, n.44, p.321-322, 2017.

MACMANUS, Concepta; NOBRE, Carlos. Brazilian Scientific Mobility Program - Science without Borders - Preliminary Results and Perspectives. Anais da Academia Brasileira de Ciência, v.89, supl.1, p.773-786, 2017.

MEC, Ministério da Educação. Conselho Nacional de Pós-Graduação. I PNPG: Plano Nacional de Pós-Graduação, s.d. Disponível em: https://www.capes.gov.br/images/stories/ download/editais/I_PNPG.pdf. Acesso em: 10 jan. 2020.

ROCHA, Maria Tereza d'Oliveira. Depoimento concedido a Marieta de Moraes Ferreira em 7 de agosto de 2001. In: Ferreira, Marieta de Moraes; Moreira, Regina da Luz (org.). Capes, 50 anos. Brasília: Capes, 2002.

SAPIRO, Gisèle. What factors determine the international circulation of scholarly books? The example of translations between English and French in the Era of Globalization. In: Heilbron, Johan; Sorá, Gustavo; Boncourt, Thibaud (org.). The social and human sciences in global power relations. Cham: Palgrave Macmillan, 2018. p.59-93.

SWAAN, Abram de. Words of the world: the global language system. Cambridge: Polity Press, 2001.

UNESCO, Organização das Nações Unidas para a Educação, a Ciência e a Cultura. Migration, déplacement et éducation: bâtir des ponts, pas de murs. Rapport mondiale de suivi sur l'éducation. Paris: Unesco, 2019. 